\title{
Contributions to the Dart versus Arrow Debate: New Data from Holocene Projectile Points from Southeastern and Southern Brazil
}

\author{
MERCEDES OKUMURA ${ }^{1}$ and ASTOLFO G.M. ARAUJO ${ }^{2}$ \\ ${ }^{1}$ Programa de Pós-Graduação em Arqueologia, PPGArq, Departamento de Antropologia, Museu Nacional, Universidade \\ Federal do Rio de Janeiro, Quinta da Boa Vista, São Cristóvão, 20940-040 Rio de Janeiro, RJ, Brasil \\ ${ }^{2}$ Museu de Arqueologia e Etnologia, Universidade de São Paulo, Av. Prof. \\ Almeida Prado, 1466, Butantã, 05508-070 São Paulo, SP, Brasil
}

Manuscript received on November 18, 2014; accepted for publication on May 13, 2015

\begin{abstract}
Lithic bifacial points are very common in the southern and southeastern regions of the Brazilian territory. Dated from Early to Late Holocene, these artifacts have not been studied in terms of their propulsion system. Given the characteristics of the bow and arrow compared to the atlatl and dart, there are important differences in the size and weight of arrowheads and dart points. Applying the techniques proposed by Shott (1997), Bradbury (1997), Fenenga (1953), Hughes (1998), and Hildebrandt and King (2012) to specimens recovered from eight sites dating from the early to the late Holocene, this work aims to present preliminary results to better understand the potential presence of darts and arrows in southeastern and southern Brazil. There was a variation in the results according to the application of different techniques. At least one set of points, dated from the Early Holocene, presented quite a high proportion of specimens classified as arrows, indicating the presence of points that could be used as arrowheads.
\end{abstract}

Key words: archaeology, arrow, atlatl, bow, dart, Umbu Tradition.

\section{INTRODUCTION}

Point-shaped lithic artifacts found in archaeological contexts are often called "arrowheads" or "projectile points". However, strictly speaking, the term "arrowhead" should not be used when referring to artifacts whose mode of propulsion was unknown. There are at least four prehistoric devices that can use lithic points. One would be the thrusting spear, which is a weapon of direct confrontation (Hughes 1998). This type of spear

Correspondence to: Mercedes Okumura

E-mail: mercedes@mn.ufrj.br is not considered a projectile, since the pressure is induced by the muscle strength of those handling the device, and directly transmitted via a shaft. The other three systems involve several means by which a projectile point can be launched: using only muscular strength, with the aid of a dart thrower (also known as atlatl) or through a bow. The projectiles launched by each device are known, respectively, as a throwing spear, dart, and arrow. These systems can be used in hunting, fishing or war (Cattelain 1997). Here, we will focus on propulsion systems using either the dart thrower or bow. 
The dart thrower comprises a cylinder or board, with a hook or groove at the end, which couples with the rear portion of the dart. The purpose of its use is to increase the initial velocity of the projectile, making a most efficient launch. The launching movement involves pivoting at the pelvis, shoulder, elbow, and wrist, the latter providing the driving force at the end of the movement. One can achieve good accuracy and high impact through its use (Cattelain 1997). The bow (in its simplest version) is basically made of a flexible and elastic part with the two ends tensioned by a string. By drawing the bow, energy is stored in the bow and transmitted to the arrow upon release (Hamilton 1982, Rausing 1967). While the dart thrower is a lever system, the bow is a spring.

The question of the origin and dispersal of the bow and arrow in the New World has important implications for understanding local cultural histories, changes in technology, work organization and socio-political interactions. Many important research questions can be addressed, from the reconstruction of cultural chronologies to the development of hunting and warfare technologies (Erlandson et al. 2014, VanPool and O'Brien 2013). In general, the adoption of the bow and arrow is connected to a new cultural-historical period and, sometimes, the arrival of a new human group (Hildebrandt and King 2012).

\section{DART VERSUS ARROW: SOME CONTROVERSIES}

Much has been discussed about the advantages and disadvantages of using the bow or the atlatl. The two technologies have been tentatively associated with the increased importance of big game hunting and war, so that the emergence of stone-tipped projectiles indicates an increase in the importance of at least one of these factors (Shea 2006). The advantages and disadvantages of using each system have been controversial among authors. There are those who advocate the superiority of the bow and arrow, which explains the idea of an almost total replacement of atlatl and dart technology by the bow and arrow in many places across the world. However, the use of the atlatl and dart presents some important advantages over the bow and arrow. For example, the use of the bow becomes almost impossible with wet or oily hands (Kellar 1955, Mason 1885, Raymond 1986). Likewise, it is impossible to protect yourself with a shield and use the bow and arrow at the same time (Swanton 1938), which justifies the fact that the Aztec warriors in historical times used the atlatl (Hassig 1988), which requires only the use of one hand to launch the projectile (Christenson 1986). Ethnographic accounts describe Tarairiu ${ }^{1}$ from Rio Grande do Norte, Brazil, using the atlatl in the right hand and a wooden club in the left hand when confronting enemies (Prins 2010). The advantage of having one of the hands free is also appreciated in the case of almost simultaneous use of a "fending stick" (Geib 1990, LeBlanc 1997, 1999) or oar blades (Dickson 1985, Whittaker 2010). Table I summarizes the main points addressed by several authors regarding the advantages of each weapon system.

\section{THE PHYSICS OF ARROWS AND DARTS}

From the physical point of view, there are important factors that can influence the penetration of a projectile, including the kinetic energy and linear momentum. Both kinetic energy $(\mathrm{K})$ and linear momentum $(\mathrm{P})$ depend on mass $(\mathrm{m})$ and speed (v) and can be jointly referred to as momentum. Kinetic energy $\left(K=(1 / 2) \mathrm{mv}^{2}\right)$ is the energy associated with the motion communicated to the

\footnotetext{
${ }^{1}$ The Tarairiu were part of the group named generically as Tapuia, a Ge language speaking group. The use of atlatl by this group can be observed in two famous works made by the mid-seventeenth century Dutch painter Albert Eckhout: "The Dance of Tapuias" and "Indian Tarairiu" (Prins 2010).

${ }^{2}$ A sort of flat wooden stick whose suggested use would be to deflect the darts thrown by another individual (Wilcox and Haas 1994).
} 
TABLE I

Advantages associated to each projectile propulsion system according to the literature.

\begin{tabular}{|c|c|c|}
\hline Bow & Dart Thrower & References \\
\hline Greater distance range & & Morse and Morse 1990 \\
\hline Easier to learn / maintain accuracy & & $\begin{array}{l}\text { Cattelain 1997, Hutchings and Bruchert } \\
\text { 1997, Reed and Geib 2013, Whittaker } \\
\text { 2010, } 2013\end{array}$ \\
\hline Arrows easier to manufacture & & $\begin{array}{l}\text { Christenson 1986, Collins 1975, Railey } \\
2010\end{array}$ \\
\hline Lighter to carry & & $\begin{array}{l}\text { Dickson 1985, Evans 1959, Mau 1963, } \\
\text { VanPool } 2006\end{array}$ \\
\hline Easier to shoot indoors & & $\begin{array}{l}\text { Dickson 1985, Hill 1948, Hughes } 1998, \\
\text { Nassaney and Pyle 1999, Reed and Geib } \\
\text { 2013, VanPool } 2006\end{array}$ \\
\hline Better for short distance & & Miller II 2009 \\
\hline \multirow[t]{7}{*}{ Greater accuracy and speed of shooting } & & $\begin{array}{l}\text { Bettinger 2013, Cattelain 1997, } \\
\text { Christenson 1986, Dickson 1985, Hughes } \\
\text { 1998, VanPool 2006 }\end{array}$ \\
\hline & Can be used with wet/oily hands & Kellar 1955, Raymond 1986 \\
\hline & Can be used with a shield & Hassig 1988, Swanton 1938 \\
\hline & One hand is free, can carry other weapons & $\begin{array}{l}\text { Dickson 1985, Prins 2010, Whittaker } \\
2010\end{array}$ \\
\hline & Can be used with a fending stick & Geib 1990, LeBlanc 1999 \\
\hline & Darts are more penetrating & Hall 1997, Raymond 1986 \\
\hline & Darts have a "knockout" effect & $\begin{array}{l}\text { Christenson 1986, Hrdlicka 2003, } \\
\text { Raymond 1986, Shott 1993, VanPool } \\
2006\end{array}$ \\
\hline
\end{tabular}

body by the potential energy transferred from an individual's muscles to the projectile through equipment such as the bow or the atlatl (O'Connell and Gardner 1972, Wilhelmsen 2001). By being squared, the speed has a greater influence than the mass in the resulting kinetic energy. Thus, it may be argued that, given the same speed, dart points (which have, on average, higher mass) would present slightly higher kinetic energy compared to arrowheads (Hughes 1998, Tomka 2013). In the case of linear momentum $(\mathrm{P}=\mathrm{mv})$, given the same velocity, dart points would present the greatest momentum (due to the larger mass). Considering the same velocity and taking into account factors such as the difference of the average mass of a dart point and an arrowhead, it seems that, in general, dart points show greater amount of penetrative ability. This possible superiority of darts in relation to arrows has important implications in their penetrating power. Darts would be more difficult to "stop" (by the skin or the bones in the case of hunting; by the armor, in case of warfare) and could cause extensive bleeding, which would be the main mechanism of death caused by this kind of projectile. Historical accounts indicate that, in the case of the Spanish conquistadors of the $16^{\text {th }}$ century, dart points were more feared than arrows, because they could easily pierce the Spanish armor (Hall 1997, Raymond 1986). In fact, these features would confer an important advantage to the use of darts compared to many other weapons used by the natives of Mesoamerica in the battles against the Spanish conquerors (Butler 1975). This greater amount of movement of the dart points would also be responsible for a greater "knockout" effect (Hrdlicka 2003), i.e., the animal would lose balance when hit, which would be a desirable effect in hunting large animals (Christenson 1986, Raymond 1986, Shott 1993, VanPool 2006). Experimental studies indicate that arrowheads would be effective 
for hunting small- and medium-sized animals and only marginally effective for killing large animals from more than 20-m distances. Very large game, such as bison, would not be easily shot down, even at just three meters away ${ }^{3}$. On the other hand, a dart thrown to a distance of 30 meters could be lethal even for a large animal (Tomka 2013). Therefore, one can assume that the atlatl would be an advantageous weapon in hunting large animals with slower flight speeds, as is the case of bison. In the case of midsized game like antelope and deer whose flight speed is high, the adoption of the bow may have represented an advantage due to the higher speed of arrows and, therefore, less time available to detect the danger and escape (Tomka 2013).

PROJECTILE TECHNOLOGY IN THE OLD AND NEW WORLD

In the Old World, projectile technology seems to have been invented independently in Europe, the Levant, and Africa, with an approximate date of 40,000 years for the earliest presence of this technology in the three regions (Farmer 1994, Shea 2006; but see Lombard and Phillipson 2010 and Sahle et al. 2013 for earlier dates). Evidence of arrows until the end of the European Upper Paleolithic (between 50,000 and 10,000 years) is scant, but in the subsequent period (the Mesolithic, which begins around 10,000 years ago), these appear to be well distributed in Europe (Bachechi et al. 1997, Bergman et al. 1988, Lansac 2001). In Japan, as well as in East and Southeast Asia, the presence of arrow points has been proposed

\footnotetext{
3 There are examples of successful hunting of large game such as bison, using the bow and arrow. This is the case of groups during late prehistory (800-250 BP or AD 200-1750) and the historical period in the Great Plains of the current territory of the United States. These hunts were held with groups on foot and horseback, who cornered the bison and shot multiple arrows from very short distances. In this case, the disadvantages related to Kinetic Energy and Moment of arrows were compensated by the number and proximity of which they were fired (Tomka 2013).
}

to date from the Late Pleistocene/Early Holocene boundary (Barton et al. 2009, Chêng Tê-K'un 1974, Nakazawa et al. 2011).

It is well accepted that the New World might have been colonized by groups with knowledge of the technology of projectiles (probably darts; Shea 2006). Direct evidence for the probable existence of darts in very ancient periods in the Americas include the projectile point found in a healed wound in the right pelvis of the Kennewick skeleton (Washington State), dated at $8750 \pm 200 \mathrm{BP}^{4}(7880$ \pm 150 14C, Taylor 2009). The projectile depth suggests a high penetration capacity, consistent with a dart point (Chatters 2001). Other examples of archaeological sites older than 8000 years BP where atlatl or fragments were found are given in Cockrell and Murphy (1978), Cressman (1977), Dixon (1999), Heizer (1951), Hester (1973), Lahren and Bonnichsen (1974), and Mildner (1974).

In the case of North America, several dates have been proposed for the emergence of the bow and arrow technology, since it is assumed that atlatls would be present in the Paleoindian period (Chard 1955, Lyman et al. 2008). In terms of direct evidence, the oldest bow in North America is dated to $1180 \pm 40{ }^{14} \mathrm{C} \mathrm{BP}$ (Hare et al. 2012), or $1120 \pm$ 60 cal BP. However, indirect evidence such as a decrease in the size of projectile points suggests a more ancient chronology. The oldest ages have been proposed for southwest Alaska, presenting small bone arrow points dated between 10,410 BP (12,350 cal BP) and 8150 BP (9120 cal BP, Maschner and Mason 2013). After 8000 BP, there is a paucity of evidence for small points considered arrowheads, although Ames et al. (2010) support

\footnotetext{
4 To standardize and allow a better understanding of the text, we chose to present the standard radiocarbon ages in the format "Before Present" (BP), and when calibrated as "cal BP". Therefore, we chose to convert most dates that were originally presented by the authors as "14C", "Before Christ" and "Anno Dommini". All calibrations were made using CalPal 2007, Hulu curve (Weninger et al. 2012).
} 
the idea of such technology in the Columbia Plateau. The bow and arrow system would have appeared (or reappeared) in the Arctic Alaska about 5000-4500 BP (around 5800 to 5200 cal BP, Blitz 1988), as part of the Arctic Small Tool tradition (Maschner and Mason 2013). In Yukon, Canada, an arrow was dated at $3510 \pm 70 \mathrm{BP}$ (and redated at $3600 \pm 40$ BP; Alix et al. 2012, Hare et al. 2012), but considered "anomalous" in that context, since the majority of the arrows found in this continental area post-dates1200 BP (see also Andrews et al. 2012, Reckin 2013).

Further South, evidence also indicates ages of 4000 BP (4500 cal BP) in eastern Washington state (Ames et al. 2010), possibly followed by 2500 $3000 \mathrm{BP}^{5}$ (2600 to $3200 \mathrm{cal} \mathrm{BP}$ ) in the region of the current states of Idaho, Oregon and Utah (Schalk and Olson 1983, Yohe II 1998). Between 2000 and 1800 years cal BP, arrow points would be present in the regions of the Great Basin, intermontane West, Northern Plains, and Alberta (Blitz 1988, Hamilton 1982). In the Great Lakes region, in the northeast of Woodlands, in the Midwest, the South and the Plains, evidence points to an introduction of the bow and arrow 1400 years cal BP or later (Blitz 1988, Weiderhold et al. 2003). According to Blitz (1988), it is clear that the bow and arrow becomes the dominant system in virtually all of North America about 1300 BP, or AD 710.

In the Mesoamerica, the use of the atlatl is well documented in both archaeological and historical terms, especially in the period of contact with the Spanish, through descriptions of chroniclers like Duran, Torquemada, Sahagun (Capitan 1911) and Garcilaso de la Vega (Swanton 1938). It seems that the bow and arrow were adopted by some Mayan groups during the Classic Period at Tikal and Caracol (AD 250 to 900; Ciofalo 2012). Aoyama (2005), through the study of linear measurements

\footnotetext{
5 For this area, there are certainly dates of 2100 years BP for
} the presence of bow and arrow (Chatters et al. 1995). and microwear analysis, suggests the presence of arrows in the Mayan lowlands at an earlier period than previously suggested (1600-1400 BP or AD 450-620). The bow and arrow would have been used by the Mayas in Post Late Classic Period (800475 BP or AD 1210-1420). However, probably due to the fact that the atlatl was considered a symbol of power (Freidel 1986, Hall 1997, Hassig 1992), the iconography of this period presents a greater emphasis on the atlatl than on the bow (LeBlanc 2003).

There are few studies that explore the question of darts and arrows in South America. There are descriptions of relatively well-preserved (but not dated) specimens of atlatls, as the one described by Uhle (1909) in Lima and southern Nazca, Peru. On the northern coast of Peru, there are some representations of the use of atlatls in Moche pottery (1900-1200 BP or AD 100-800), referring to both warfare and hunting contexts, although other weapons are represented more frequently (Whittaker 2006). Several petroglyphs (possibly from the Archaic period) strongly suggest the use of atlatls in southern Peru, in Cuzco (Hostnig sinus data) and Carabaya (Hostnig 2003). Regardless of their presence in the writings of some chroniclers (Cobo 1890-1893 [1953] IV, Las Casas 1892, Garcilaso de La Vega 1960-1963) the use of atlatls in the Peruvian Inca period seems to have been rare (Métraux 1949, Rowe 1946).

In Colombia, there is evidence of the use of both the atlatl and bow in the Muisca Empire (1300$400 \mathrm{BP}$ or 710-1510 AD). There are reports of an atlatl associated with a mummy of the late period of this culture (700-550 BP or 1300-1360 AD; Bruechert 1998), miniature atlatls made of gold used as funerary offerings, as well as numerous anthropomorphic figurines made of metal (called "Tunjo") that feature bows and arrows (Marriner 2002).

Evidence from the northern coast of Chile seems to point to an important role of atlatls, 
especially in the Chinchorro Culture. Bittman and Munizaga (1984) describe an atlatl placed within a Chinchorro mummy in Arica, possibly dated between 5000 and $4000 \mathrm{BP}\left(4^{\text {th }}\right.$ and $3^{\text {rd }}$ millennium BC). Similar findings were reported for the same area (northern Chile coast), most for the same culture by several authors (Bird 1943, 1946, Focacci 1974, Munizaga 1964, Núñez 1963, Rivera 1975, Uhle 1919). In inland northern Chile, there are reports of atlatls (or parts of) in Tatalpe, possibly related to Tihuanaco (Latcham 1938), as well as in the site Tambillo 1, dated at $9650 \pm 160$ cal BP (8590 \pm 130 BP, Núñez 1992). In the central region of Chile, there are ethnohistorical reports of the use of atlatls by Picunches groups (de Lobera et al. 1970).

Bittmann and Munizaga (1979) describe a bow of $156 \mathrm{~cm}$ used as a support structure of a Chinchorro mummy, placing a minimum date for the occurrence of the bow and arrow in South America between 7000 and 3700 BP (5900 and $2100 \mathrm{BC}$, which is the period associated with the mummification in Chinchorro culture, Arriaza 1995). Other findings confirm the presence of bows in association with Chinchorro mummies (Muñoz et al. 1991, Uhle 1917, 1919, 1922, 1974). However, Lavallée (2000) states that the identification of this piece of wood used to strengthen and maintain a stable structure of the mummy as a bow remains uncertain. In the specific case of the finding described by Uhle (1922), Owen (1998) considers that the evidence for the piece of wood found inside the mummy be a bow is rather weak. In relation to the finding described by Muñoz et al. (1991), Owen (1998) claims to be quite plausible to be a bow, however, there are problems with the sequence of radiocarbon dates obtained for the site. Anyway, according to the author, the approximate date of 990 ca BC $(2840 \pm 100 \mathrm{BP})$ obtained for a burial from the same part of the site suggests the presence of the bow and arrow in the northern coast of Chile during this period. The association between the
Chinchorro groups and the bow and arrow remains quite problematic, since Arriaza et al. (2008) mention that the Chinchorro groups would be very adapted to fishing and that the artifacts commonly found in archaeological sites would be harpoons and atlatls. No reference to the bow and arrow is made by these authors. More detailed studies addressing this material and its chronology are essential for a better understanding of the origins of bow and arrow in that region.

Other studies point to a less ambiguous presence of the bow and arrow in Chile in later periods. Métraux (1949) draws attention to the presence of bows drawn in textiles found in Tihuanaco, without giving more information about the period. In Chiribaya Alta, a set of bow and arrows was described, the more conservative timeline for that culture would be between 1025 and 625 BP (1010 and 1330 AD, Owen 1998). Some authors (De Souza 2004, Fernández Distel 1977, Focacci and Chacón 1989) suggest a date between 2500 and $3500 \mathrm{BP}$ (640 and $1830 \mathrm{BC}$ ) for the presence of the bow in northern Chile. Others argue that such presence would certainly be between 1000 and 650 BP (1040 and 1320 AD), Late Intermediate Period) in groups from the southern coast of Peru and northern coast of Chile (Owen 1998). In the Atacama desert the finding of bows and arrows as funerary goods, as well the presence of arrows embedded in bones, attest the presence of this technology since AD 400 (Lessa and Mendonça de Souza 2003, Torres-Rouff and Knudson 2007).

In the Argentinian Puna, many authors (Casanova 1944, Fernández Distel 1977, Vignati 1936) describe well-preserved specimens of atlatls, but no dates are associated with them. In San Juan, western Argentina, there is a description of an atlatl discovered by Gambier and Sacchero (1969), related to archaeological levels dated at $5060 \pm 200$ cal BP $(4410 \pm 150$ BP $)$. In a South American context, Ratto (1992) has been one of the few authors to discuss how different projectile 
points could be associated to different systems (throwing spear, dart or arrow), using the physical and mechanic properties of raw material, as well as the metrical variables and the aerodynamic design of the projectile points. The author uses this set of variables to propose which systems are present in Tierra del Fuego, concluding that there were arrow points, throwing spear, and knives (Ratto 1992). Ratto (1994) also investigated the points type Bird IV and V from Patagonia, dated from the Mid Holocene onwards (earliest age at $4560 \pm 130 \mathrm{BP}$, or $5230 \pm 200$ cal BP; see Franco et al. 2009 for a discussion on the chronology and morphological variability), concluding that the small Bird V points from El Volcán would be arrow points and that the bigger Bird IV points would be throwing spears (but see Prieto 1989-1990 for a different view). In fact, the reduction in point size in the Middle Holocene has been observed in other Argentinian regions, like in Puna, but it has been interpreted as a result of changes in subsistence strategies, including residential mobility and the beginning of camelid domestication, rather than a change in projectile technology (Cardillo 2009).

In Brazil, there have been no studies on the use of the bow and arrow in prehistoric times. Three shafts made of whale bone that could be atlatls were found in two coastal shellmound sites from northern Santa Catarina state: Morro do Ouro (4500 $\pm 60 \mathrm{BP}$, or $5160 \pm 110$ cal BP, Wesolowski 2000) and Conquista (Prous 1991a). There are a few rock paintings representing anthropomorphic figures holding possible atlatls: that is the case of paintings from Nordeste and São Francisco traditions, both from northeastern Brazil. However, there have been no explicit hunting scenes using the atlatl: in Piauí state, such weapons seem to be used in warfare contexts. In the Planalto tradition, located mainly in central Minas Gerais state, there are also representations of animals with shafts implanted in their dorsal area, sometimes surrounded by anthropomorphic figures (Prous 1991b). There are no dates associated with these rock art traditions, although the Planalto tradition can be tentatively dated around the mid and late Holocene in Minas Gerais (Prous and Baeta 1992-1993).

In short, there is little archaeological direct evidence of the use of atlatl or bow in South America (Whittaker 2010). As a result, most studies on the subject have been done almost exclusively from the kind of projectile points that are tentatively assigned to one or the other system.

In Brazil, no studies have been developed taking into account the propulsion system of the different projectile points during prehistory, regardless the abundance of sites yielding bifacial points (for a preliminary result, see M. Okumura, unpublished data). Therefore, this article is an initial attempt to organize data and present preliminary ideas on this issue for Southeastern and Southern Brazilian sites.

\section{MATERIALS AND METHODS}

Stemmed projectile points from eight archaeological sites from southeastern and southern Brazil were selected. The selection criteria took into account the presence of a fairly large number of projectile points in archaeological levels, the evidence for a single occupation (or at least homogeneity of material culture across archaeological levels) and the existence of radiocarbon dates for each site. Table II presents the archaeological sites and their absolute and calibrated radiocarbon dates. Figure 1 presents the location of each site (see column on Table II) and a brief description is given in the supplementary material.

The archeological sites analyzed show a lithic technology that is commonly found in the southern part of Brazil, called Umbu Tradition. Its original "definition" from the late 1960's is somewhat problematic (Miller 1967, 1974), based mainly on the presence of a single cultural item (bifacial points), and the range of ages (between 12,000 cal BP and 500 cal BP; Schmitz 1987) was considered 
TABLE II

Archaeological sites, absolute dating (14C years BP), the code of the laboratory, and calibrated radiocarbon dates (cal years BP). Sites are ordered from the most ancient to the most recent dates. The dates can be found in Araujo 2012, Brochado and Schmitz 1972-1973, Chmyz et al. 2008, Dias 2012, Mentz Ribeiro et al. 1989, Mentz Ribeiro and Ribeiro 1999, Miller 1974, Schmitz 2006, Okumura and Araujo 2014). The dates were calibrated using CalPal and the calibration curve Intcal98.

\begin{tabular}{|c|c|c|}
\hline Site & $14 \mathrm{C}$ Years BP & Cal years BP \\
\hline PR-WB-16: Tunas & $\begin{array}{l}9630 \pm 40(\text { Beta } 210872) \\
7170 \pm 60(\text { Beta } 210871)\end{array}$ & $\begin{array}{c}10,980 \pm 140 \\
7980 \pm 70\end{array}$ \\
\hline \multirow{4}{*}{ RS-TQ-58: Garivaldino } & $9430 \pm 360($ Beta 44739$)$ & $10,720 \pm 470$ \\
\hline & $8290 \pm 130($ Beta 32183$)$ & $9260 \pm 170$ \\
\hline & $8020 \pm 150($ Beta 33458$)$ & $8920 \pm 240$ \\
\hline & $7250 \pm 350($ Beta 44740$)$ & $8090 \pm 330$ \\
\hline \multirow{4}{*}{ RS-C-61: Adelar Pilger } & $8430 \pm 50($ Beta 260455$)$ & $9440 \pm 60$ \\
\hline & $8150 \pm 50($ Beta 260456$)$ & $9130 \pm 80$ \\
\hline & $8030 \pm 50($ Beta 229583$)$ & $8930 \pm 130$ \\
\hline & $6180 \pm 50($ Beta 227856$)$ & $7080 \pm 90$ \\
\hline \multirow{2}{*}{ RS-217: Pedro Fridolino Schmitz } & $7800 \pm 50($ Beta 204345) & $8560 \pm 70$ \\
\hline & $1400 \pm 40($ Beta 211727$)$ & $1320 \pm 30$ \\
\hline \multirow{2}{*}{ Alice Boer } & $7680 \pm 40$ (Beta 320199) & $8470 \pm 50$ \\
\hline & $7200 \pm 40($ Beta 320198$)$ & $8020 \pm 60$ \\
\hline \multirow{3}{*}{ RS-LN-01: Dalpiaz } & $5950 \pm 190$ (SI 234) & $6800 \pm 240$ \\
\hline & $5680 \pm 240($ SI 235) & $6490 \pm 270$ \\
\hline & $4280 \pm 180($ SI 233$)$ & $4870 \pm 280$ \\
\hline RS-C-14: Bom Jardim Velho & $5655 \pm 140$ (SI 1199) & $6470 \pm 150$ \\
\hline RS-S-308: Morro da Flecha 1 & $575 \pm 80$ (SI 804) & $590 \pm 50$ \\
\hline
\end{tabular}

too wide to represent a single, culturally linked population. However, recent studies suggest that there is indeed a strong cultural bond across time and space (Okumura and Araujo 2014), or that the notion of a stable lithic bifacial point tradition is warranted for the southern sites, which comprehend a vast area (around $510,000 \mathrm{~km}^{2}$ ). Because of the availability of ages, our sample is biased towards the southernmost sites (Figure 1), inside rockshelters, and located mostly in Rio Grande do Sul (RS) state. Two of the sites are located in a northern setting Tunas rockshelter in Paraná (PR) state, and Alice Boer in São Paulo (SP) state. The points recovered from Alice Boer site present shapes that are morphometrically (statistically) different from the southern sites, and therefore may represent a different cultural sphere (Okumura and Araujo 2013). As a result, although studies indicate a relative homogeneity in the morphology of these bifacial points in Southern Brazil, such scenario cannot be sustained for northern locations like São Paulo state (Okumura and Araujo 2013). Figure 2 presents an overview of the morphology of the analyzed points.

Several authors have suggested different techniques to classify projectile points as either darts or arrows (Ames et al. 2010, Bradbury 1997, Browne 1938, Corliss 1972, Evans 1957, Fawcett and Kornfield 1980, Fenenga 1953, Hildebrandt and King 2012, Hughes 1998, Ratto 1992, 1994, Shott 1997, Thomas 1978). We used the techniques proposed by Fenenga (1953), Bradbury (1997), Shott (1997), Hughes (1998), and Hildebrandt and King (2012) to explore the hypothesis that different propulsion systems may have been present in southern and southeastern Brazil during prehistory. 


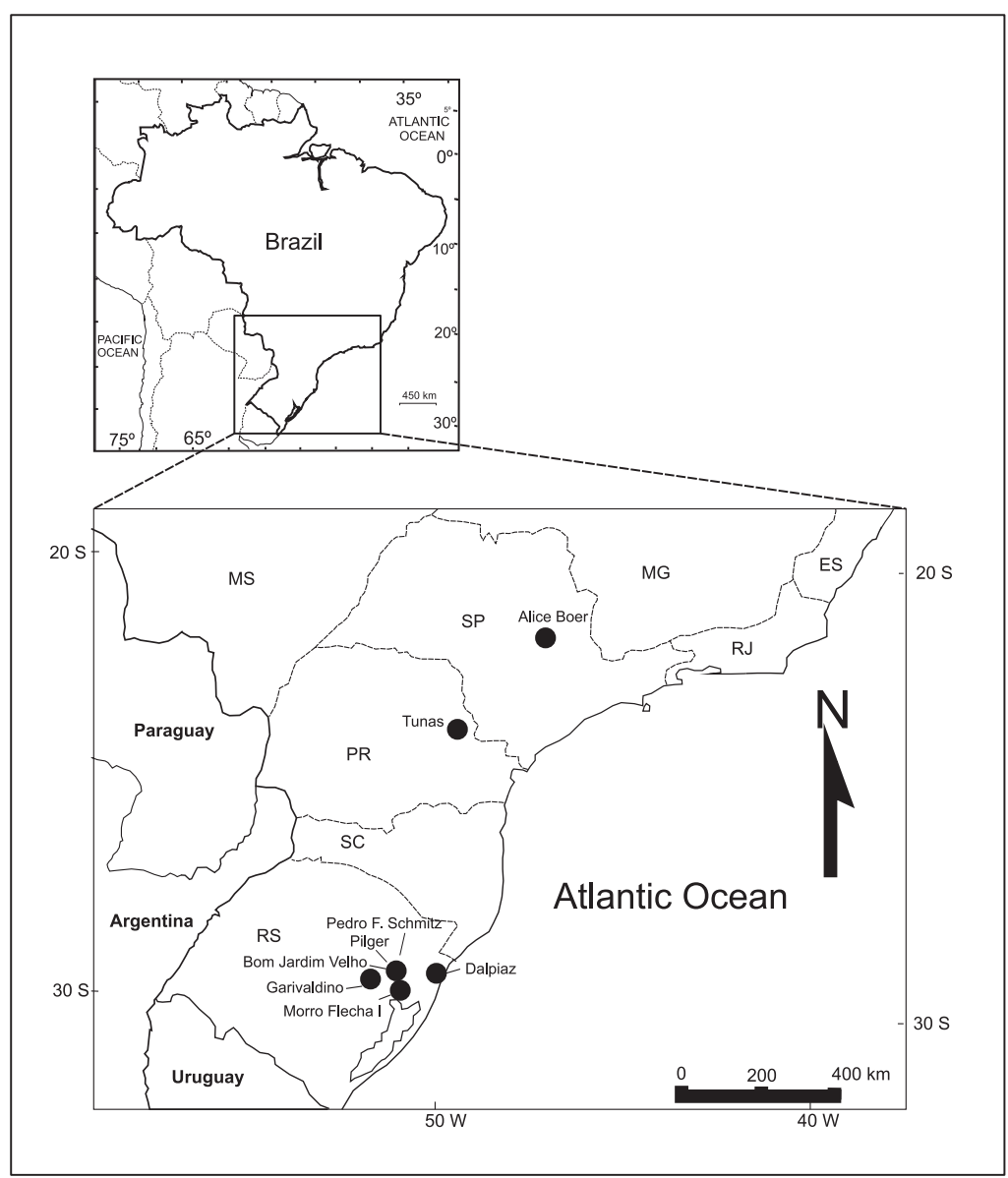

Figure 1 - Location of the analyzed sites.

These techniques can be divided in two groups. The first group uses functions derived from a Discriminant Function Analysis based on ethnographic or archaeological specimens whose propulsion system was known. The other group considers a threshold value of a given linear measurement to distinguish arrowheads from dart points. The first group includes Shott (1997) and Bradbury (1997). The technique proposed by Shott (1997) was based on the work of Thomas (1978), which used measurements taken from museum specimens (ethnographic and archaeological North American points) whose propulsion system was known due to the presence of the original shafts together with projectile points. Shott (1997) used the sample of 132 specimens of arrows analyzed by Thomas (1978) and increased the sample of darts to
39 specimens. Using four linear measurements, he calculated four pairs of equations from Discriminant Function Analysis. Such equations use four (length, shoulder width, thickness, and neck width), three (shoulder width, thickness, and neck width), two (shoulder width and thickness), or one variable (shoulder width) to estimate the proportion of darts and arrows from a given sample. Although Shott (1997) states that the equation with only one variable is the one that has better discrimination between the darts and arrows of the sample in question (85\%), we chose to use all four equations due to the fact that the number of specimens that could be included in each analysis (i.e., four, three, two or one variable) is variable. Bradbury (1997) also employed equations from Discriminant Function Analysis to discriminate arrows from darts, but used neck width and maximum width. 


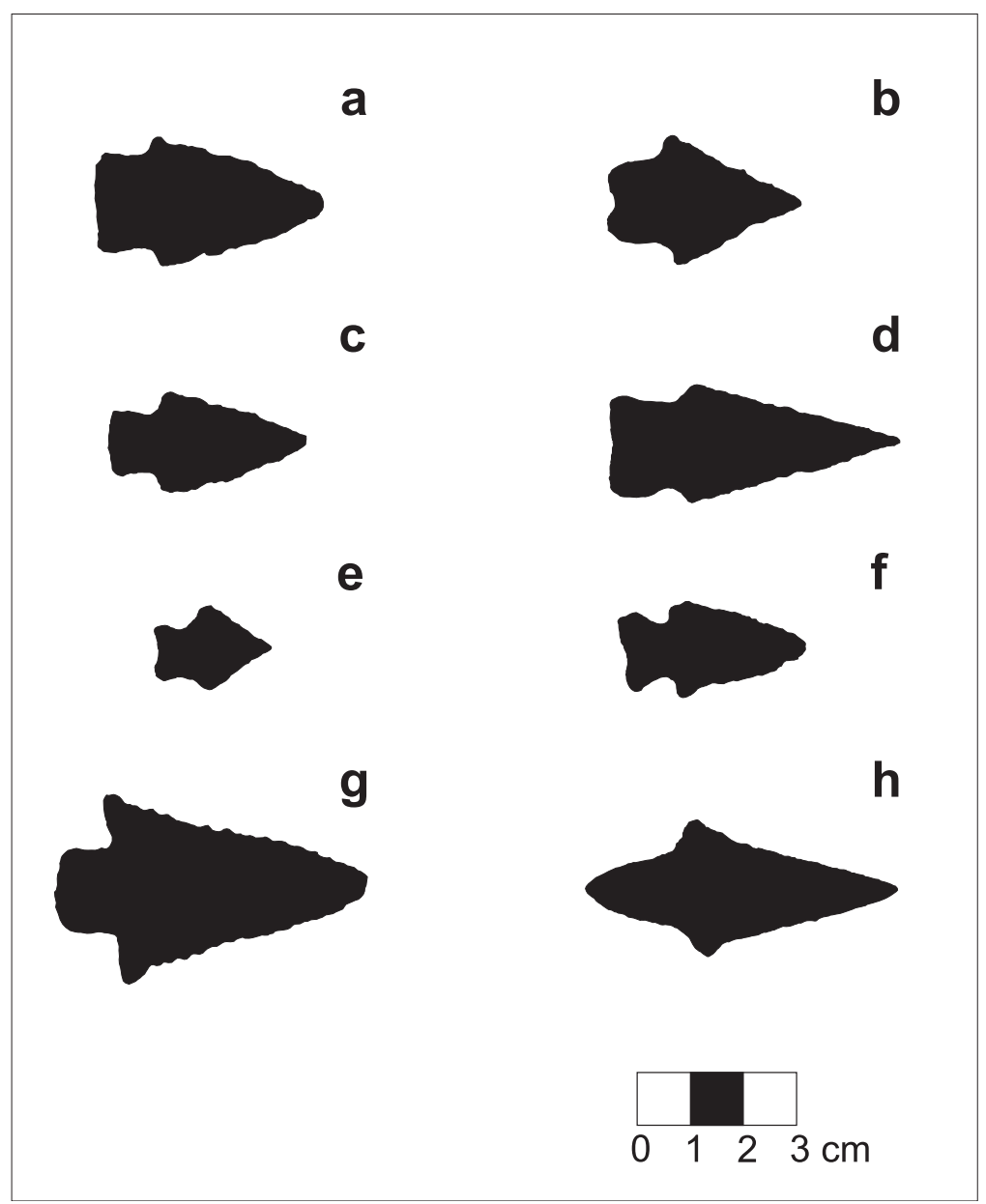

Figure 2 - Overview of the morphology of the analyzed points. a: Bom Jardim Velho (RS); b: Adelar Pilger (RS); c: Dalpiaz (RS); d: Garivaldino (RS); e: Tunas (PR); f: Morro da Flecha 1 (RS); g: Pedro Fridolino Schmitz (RS); h: Alice Boer (SP).

The techniques proposed by Fenenga (1953), by Hughes (1998), and by Hildebrandt and King (2012) represent a group that establishes a threshold value of a particular measurement to distinguish arrow points from dart points. Fenenga (1953) and Hughes (1998) set a threshold value of $3 \mathrm{~g}$ : points weighing $3 \mathrm{~g}$ or more would be considered as darts and those weighing less than $3 \mathrm{~g}$ would be classified as arrows. As VanPool (2006) discusses, such limit value was based on the physics of projectile flight. Hildebrandt and King (2012) propose that when the sum of the neck width and maximum thickness values is greater than $11.8 \mathrm{~mm}$, the projectile is classified as a dart, whereas values smaller than $11.8 \mathrm{~mm}$ would indicate an arrow.

\section{RESULTS}

Table III presents the number of specimens from each site that were classified as darts or arrows and the percentage of specimens classified as arrows for each Shott (1997) equation, with different numbers of variables. Table IV presents the number of specimens from each site that were classified as darts or arrows and the percentage of specimens classified as arrows, as well as the total number of analyzed specimens using Bradbury (1997) equation. 

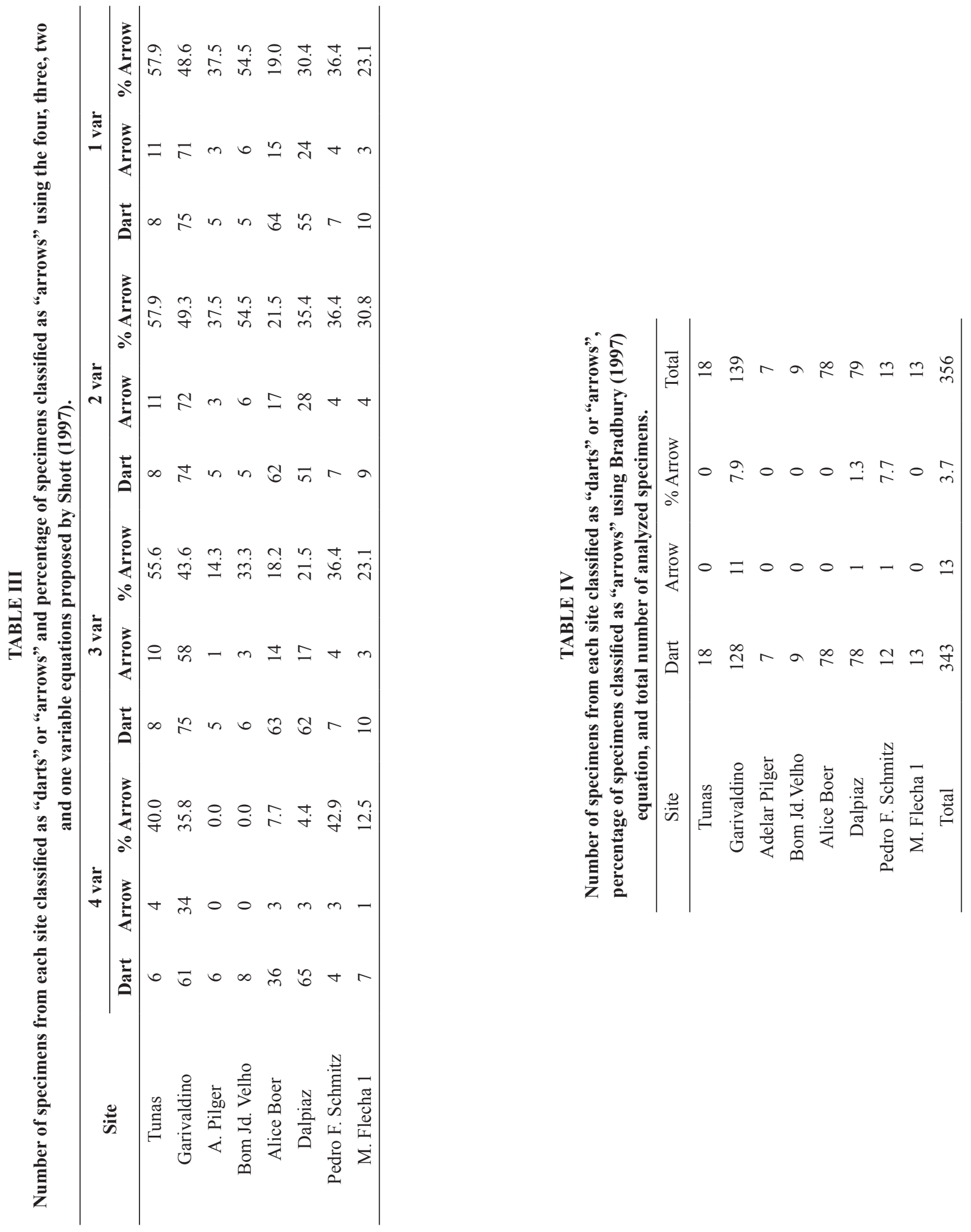
Figure 3 shows a graph presenting the percentage of classification using the equations proposed by Shott (1997) and by Bradbury (1997). Because the percentages of darts and arrows are complementary, we chose to present only the percentage of arrows. The equation by Bradbury (1997) classifies the vast majority of the points as darts. However, the equations by Shott (1997) present a very different picture. Some sites maintain a higher proportion of darts in relation to arrows regardless of the equation. This is the case of Adelar Pilger, Alice Boer, Dalpiaz, Pedro F. Schmitz, and Morro da Flecha 1. On the other hand, the proportion of points that are classified as arrows is fairly large, especially in the two oldest sites (Tunas and Garivaldino). Even more intriguing is the fact that, regardless of the number of variables, Tunas presents at least $40 \%$ of the points classified as arrows, reaching almost $60 \%$. Even if we take into account the small sample size represented by Tunas (10 to 19 points), the same pattern is still observed in Garivaldino (95 to 146 points). In our view, these results strongly suggest the presence of projectile points that could have been used as arrows.
Table V presents the total number and the number of specimens from each site that were classified as arrows according to the threshold values proposed by Hildebrandt and King (2012) and by Fenenga (1953) and Hughes (1998), and the results are graphically shown in Figure 4.

The results using the threshold by Hildebrandt and King (2012) are very similar to the ones obtained using the functions by Bradbury (1997): the majority of the points are considered dart points. On the other hand, using the threshold value proposed by Fenenga (1953) and Hughes (1998), it is possible to verify that all sites but two (Alice Boer and Dalpiaz) present a high relative proportion of points that could be used as arrows. For Garivaldino, almost a third of the points would be considered as arrows, and for Adelar Pilger and Morro da Flecha 1, this proportion is quite balanced, around 50\%. Again, Tunas shows the highest proportion, with $72 \%$ of arrows, suggesting the likely presence of projectile points that could be used as arrowheads.

Another way of exploring the possible existence of different projectile propulsion systems

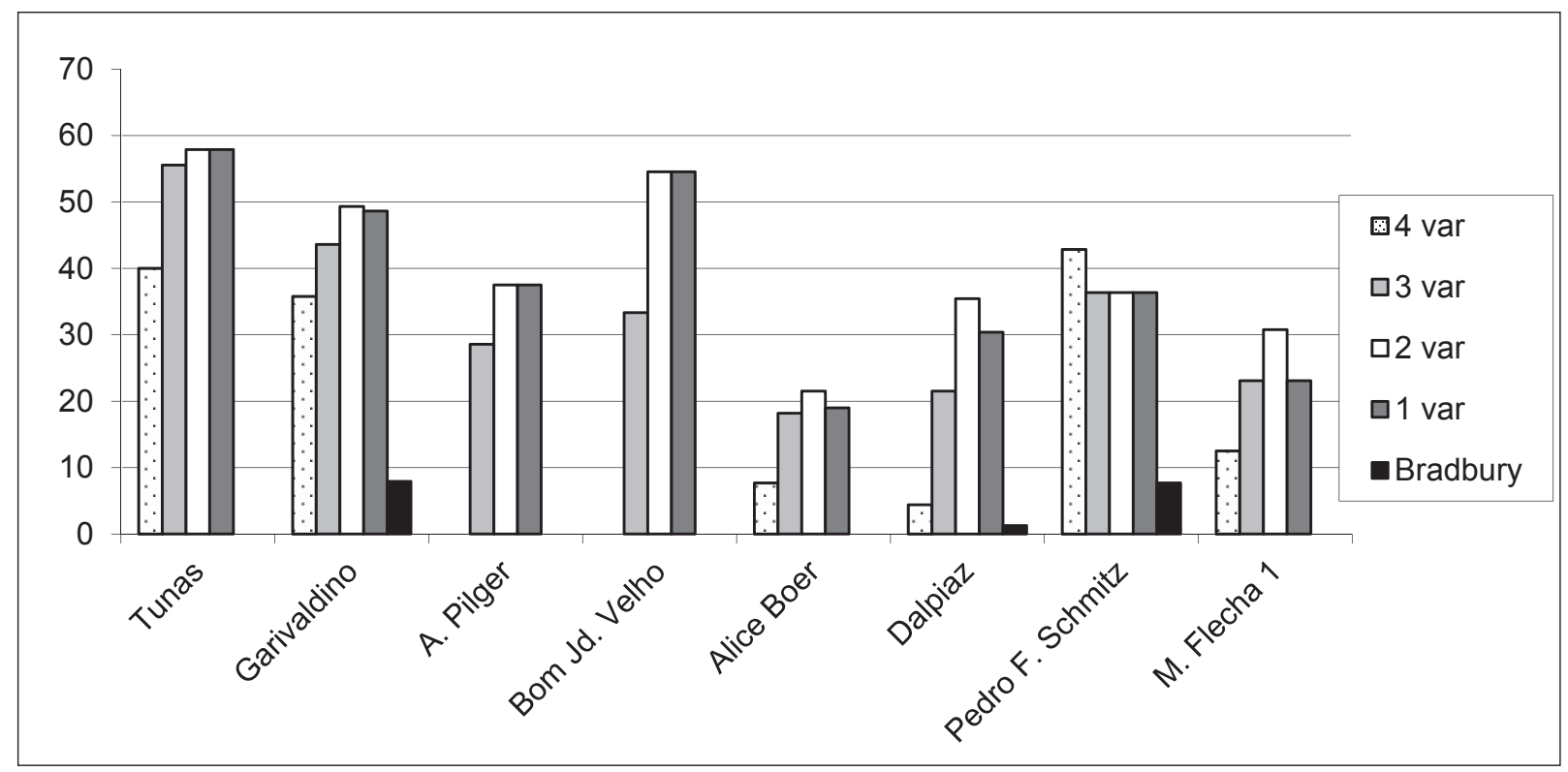

Figure 3 - Graph presenting the percentage of arrow classification using the equations proposed by Shott (1997) and by Bradbury (1997). 
TABLE V

Number and percentage of specimens from each site classified as "arrows" according to the threshold valued proposed by Hildebrandt and King (2012) and by Fenenga (1953) and Hughes (1998), and total number of analyzed specimens.

\begin{tabular}{ccccccc}
\hline & \multicolumn{3}{c}{ Hildebrandt and King (2012) } & \multicolumn{3}{c}{ Fenenga (1953), Hughes (1998) } \\
Site & \# Arrow & Total & $\%$ & \# Arrow & Total & $\%$ \\
\hline Tunas & 0 & 33 & 0.0 & 18 & 25 & 72 \\
Garivaldino & 3 & 157 & 1.9 & 51 & 170 & 30 \\
A.Pilger & 0 & 7 & 0.0 & 4 & 9 & 44.4 \\
Bom Jd. Velho & 0 & 10 & 0.0 & 5 & 13 & 38.5 \\
Alice Boer & 1 & 116 & 0.9 & 17 & 120 & 14.2 \\
Dalpiaz & 0 & 88 & 0.0 & 2 & 88 & 2.3 \\
P.F. Schmitz & 0 & 21 & 0.0 & 7 & 22 & 31.8 \\
M.Flecha & 0 & 18 & 0.0 & 7 & 16 & 43.8 \\
\hline Total & 4 & 450 & & 111 & 463 & \\
\hline
\end{tabular}

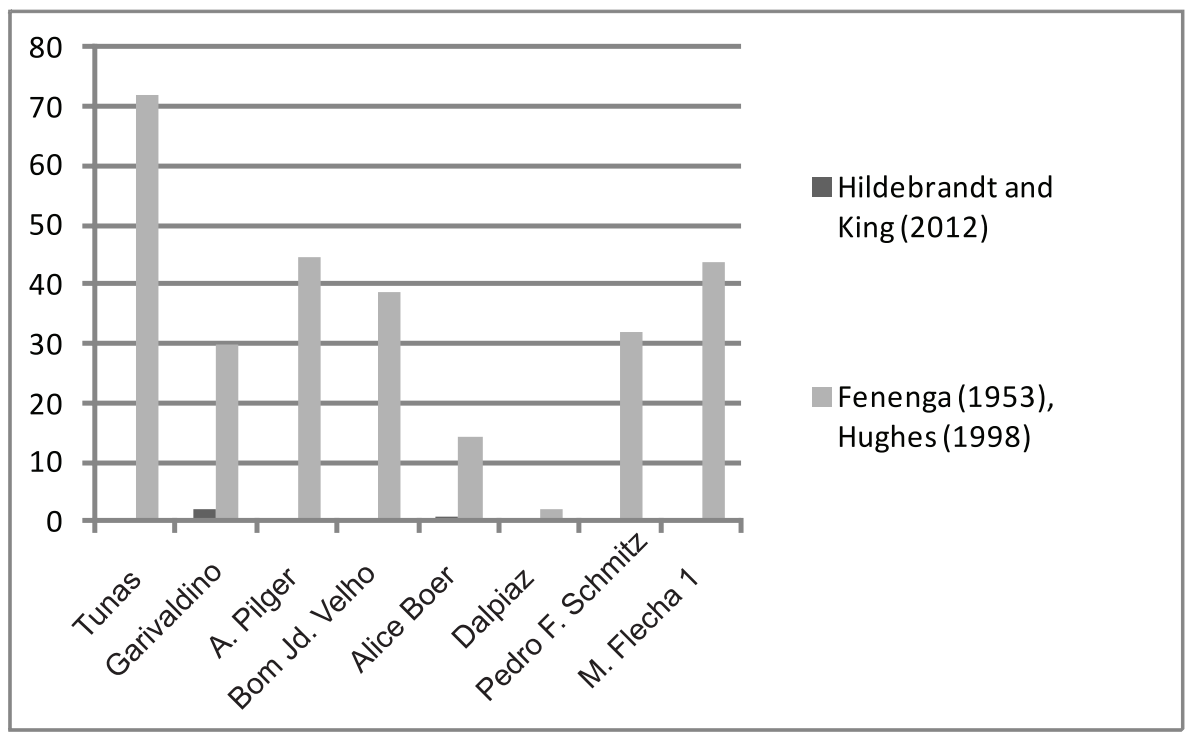

Figure 4 - Graph presenting the percentage of arrow classification using the threshold values proposed by Hildebrandt and King (2012) and by Fenenga (1953) and Hughes (1998).

is by means of checking the behavior of the frequencies: bimodality can be theoretically a good indicator of both bow and atlatl (Ciofalo 2012, Fenenga 1953), since arrow points would cluster in one end of the spectrum, and dart points on the other, with few points in the middle. If, on the other hand, only one propulsion system is in use, we can expect a unimodal pattern since points are being made with a single purpose, the sizes varying due to resharpening or differences in raw materials and knapping skills.

When we compare Garivaldino and Alice Boer (Figure 5a-f), two of the sites with large sample sizes and whose results using the thresholds suggested by Fenenga (1953) and Hughes (1998) show very different proportions of darts or arrows (Table V), important patterns emerge. The bimodality is apparent in Garivaldino, with two 


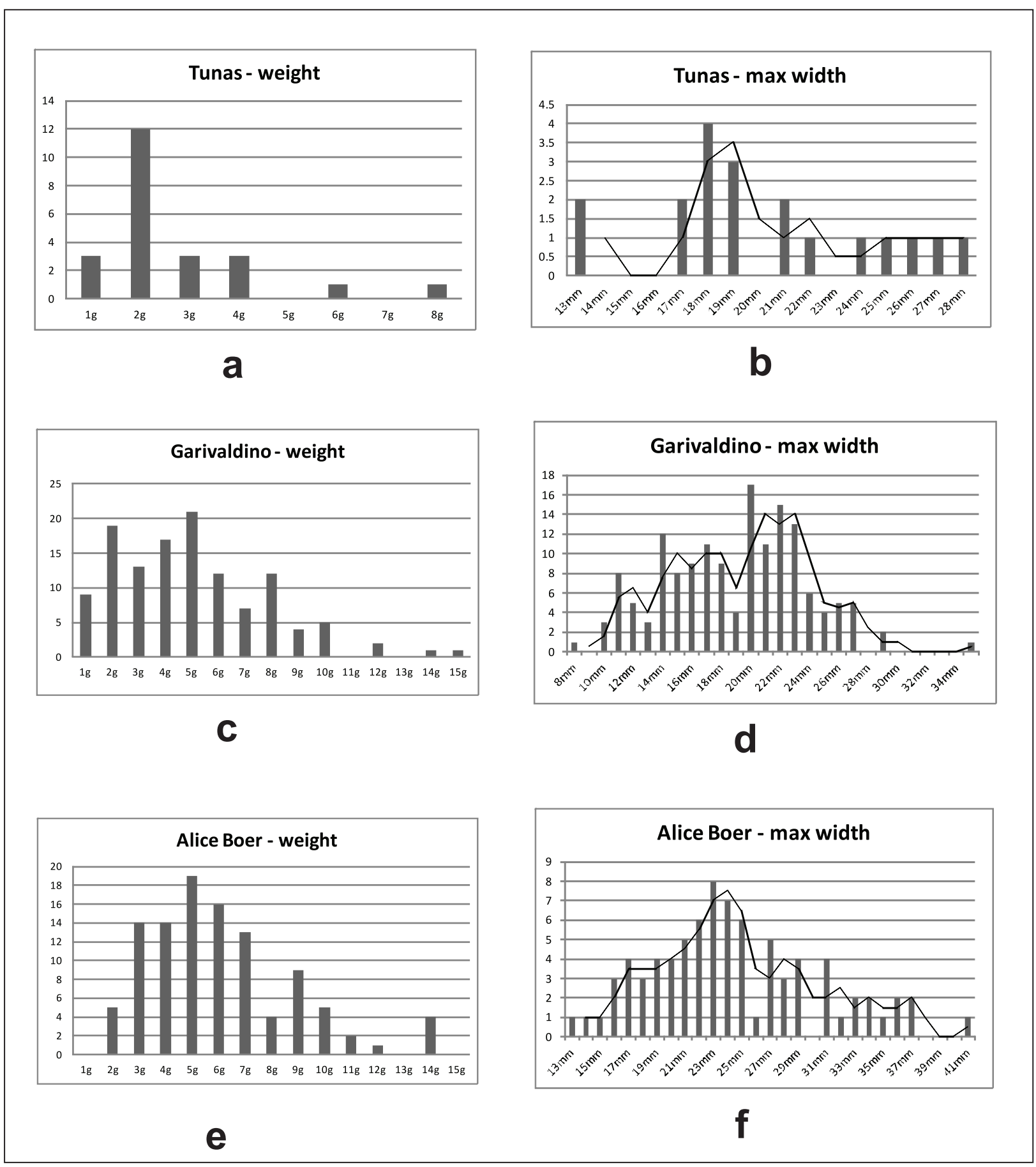

Figure 5 - Weight and maximum width distribution observed in the sample of points from Tunas (respectively, a and b), Garivaldino (c and $\mathbf{d})$, and Alice Boer (e and $\mathbf{f})$.

peaks, one at $2 \mathrm{~g}$ and the other at $5 \mathrm{~g}$, while Alice Boer seems unimodal, with a peak at $5 \mathrm{~g}$ (Figure 5c). This suggests the presence of both arrows and darts at Garivaldino, while in Alice Boer darts would be the main projectiles, with a peak around $5 \mathrm{~g}$ (Figure 5e). At Tunas, in spite of the smaller sample size, the pattern is also unimodal, with a peak at $2 \mathrm{~g}$ (Figure 5a), and most points weighting 
less than $3 \mathrm{~g}$ (which is the threshold value proposed by Fenenga [1953] and Hughes [1998]), suggesting a very strong presence of points that could be used as arrows. Importantly, the bimodal pattern in Garivaldino seems to occur on both sides of the $3 \mathrm{~g}$ threshold value, suggesting again that we have a cluster of points with a peak in $2 \mathrm{~g}$ (arrows) and another cluster with a peak in $5 \mathrm{~g}$ (darts). The same pattern is observed if we use a measure of maximum width, that is robust against resharpening (Figure 5b, d, f - see Ciofalo 2012). In short, Garivaldino seems a mixture of two samples, while Tunas and Alice Boer are extremes showing, respectively, strong presence of arrows and darts.

\section{DISCUSSION}

The results show that, in general, the examined sites presented a higher proportion of darts in relation to arrows and that this proportion can change according to the equation applied, ranging from almost $100 \%$ of darts, a balanced (50-50) proportion, to percentages of darts below $50 \%$. The application of the techniques proposed by Bradbury (1997) and Hildebrandt and King (2012) have yielded very similar results, pointing to a massive majority of dart points in our sample. However, the technique suggested by Hildebrandt and King (2012) has been criticized by Walde (2013) due to its poor performance in identifying specimens from the Canadian Plains where archaeological, written, and ethnographic evidence strongly points to their use as arrow points. The same technique has also been pointed out as problematic by Erlandson et al. (2014), when applied to coastal settings where harpoon points might have been used for fishing and hunting.

Taking into account the other techniques, it is possible to explore the possibility of the presence of different types of projectile propulsion systems in our sample. Being conservative, sites with percentages of arrows that fall above $50 \%$ may indicate the presence of small points that would potentially have been used as arrows. Noteworthy is the fact that Tunas rockshelter, the site that presented in a more systematic way quite high percentages of points classified as arrows, is dated from the Pleistocene/Holocene transition. This pattern appears to be contrary to the expectation that presupposes that the presence of arrows is always later than the darts in chronological terms, and thus finding a higher proportion of arrows in relation to darts at most recent sites would not have been a surprise. It is also worth noting that this data suggests the presence of projectile points whose morphology would be liable to be considered "arrows" in sites whose dates are well beyond most of the earlier proposed dates for the emergence of bow and arrow technology, both in North America, as well as in the rest of South America (even when considering the ancient bows presumably associated with Chinchorro mummies).

On the other hand, some samples presented a strong tendency of either a greater proportion of darts in relation to arrows or a very balanced proportion of potential darts and arrows (Adelar Pilger, Alice Boer, Dalpiaz, Pedro F. Schmitz, and Morro da Flecha 1). That could be indicating either the presence of a great range of variation in point size which could be part of the cultural repertoire of these groups or the mixing of older (supposedly bigger) points with more recent (and smaller) points. However, the discreet, thin archaeological layers observed at least in Alice Boer and in Morro da Flecha 1 strongly indicates the presence of a single occupation and the absence of any mixing of materials from much older contexts to younger ones. Therefore, it seems that least for these sites, points from different sizes were being manufactured. Such scenario has been observed also in the northern Patagonian coast. According to Cardillo and Alberti (2014), if some elements that are crucial for the good performance of arrowheads were already present in other types of 
points (associated to different projectile systems), that could have decreased the costs of invention or adoption of the bow and arrow technology, because major innovations would not have been needed in their initial creation or adoption.

One of the most accepted methods for discriminating between different projectile propulsion systems is the one proposed by Shott (1997), in which points are classified as darts or arrows from equations derived from Discriminant Functions obtained from samples of projectile points whose system used (atlatl or bow) was known. This method seems to have more satisfactory results than the use of threshold values to classify points as darts or arrows (Shott 1997). However, one should take into account that it is not because there is a percentage of points classified as arrows that there are necessarily arrows in the sample. This follows from the percentage of misclassifications observed for each of the four equations in the sample Shott (1997). It is more likely that darts, as opposed to arrows, are under-represented in a given sample (VanPool 2006). According to Shott (1997), the shoulder width would be the variable that best distinguishes the different types of points and although a threshold value can be used, there seems to be a higher percentage of correct classification when the single variable equation is used. The percentages of incorrect classification are mainly due to the fact there is an overlap in the distribution of the measurements of darts and arrows (Shott 1997). For example, points with wide necks may have been used as arrows, and points with narrow necks may have been used as darts (VanPool 2006). Accordingly, VanPool (2006) points out that determining whether a point can be associated with a dart or arrow is a statistical argument. In fact, it is quite impossible to determine whether a given point is dart or arrow, however, it is possible to estimate if a reasonably large sample contains more arrows, more darts or a similar proportion of both (Fenenga 1953, Shott 1997). Sites that show a tendency to a lower proportion of darts in relation to arrows, as is the case of Tunas, may be signaling the presence of sets of artifacts representing mostly arrowheads. It is also important to remark that among all studied sites, only Garivaldino, Alice Boer, and Dalpiaz have a reasonably large sample size, so the results obtained for these sites would be more reliable than those observed for sites whose sample size is smaller.

Other aspects that can cause noise in analyses that use the size of points to infer their use is the fact that small points can be used as darts (Rausing 1967, Thomas 1978, Lombard et al. 2004), as long as their smaller mass is compensated by a heavier shaft (Whittaker 2007). Still, according to some authors, the low quality of the raw material can make points become smaller in size (Andrefsky Jr 1994, Fawcett and Kornfield 1980). Finally, the resharpening of the points can modify their length, width, and thickness (Hoffman 1985, see Reed and Geib 2013 for a critique on resharpening and Shott's sample), although Lyman et al. (2009) state that resharpening could not change the general framework. In fact, some regions of the points are more likely to be modified when resharpened. It is clear that the body of the point is the part with the greatest potential to be modified, while regions such as the neck and stem would be less affected by this process (Charlin and González-José 2012). Thus, it can be suggested that the equations by Shott (1997) that would be most affected by the revival would be the four-variable equation, which includes length. Nevertheless, the variables that appear to be most important for discrimination (width and shoulder thickness, Shott 1997) would not be very affected by possible resharpening events. So far, there are no studies on how different hafting techniques might affect regions like the neck and the stem; the question on how "Umbu" points were hafted is also a topic which needs to be addressed in the future.

Another problematic aspect of using equations is the inability to distinguish points that have been 
used for purposes other than projectile points. It is known that points can also be used as awls, knives, spears, harpoons, among other uses (Ahler 1971, Erlandson et al. 2014, Fenenga 1953, Greaves 1997, Kay 1996, Morrisey 2009, Pitt Rivers 1906 , Rausing 1967). Therefore, it is necessary to include in future studies the examination of use wear to determine how these artifacts were used (Kay 1996), analysis of knapping scars to understand how the tool was made and (if applicable) resharpened (Harper and Andrefsky Jr 2008), as well as a study of the patterns of fractures of the broken points to understand their impact velocity (Morrisey 2009, Odell and Cowan 1986). It would also be important to study the faunal contents (when available) of the analyzed sites, in order to detect potential changes in the faunal composition that might indicate changes in hunting techniques (as observed by Cardillo and Alberti 2014 in northern Patagonia). The analysis of faunal remains of Dalpiaz, Bom Jardim Velho, Adelar Pilger and Garivaldino (Rosa and Jabocus 2010) indicates a generalist pattern of faunal exploitation, with a predominant preference for medium (3-20 kg) to large (20-60 kg) mammals, as well as reptiles, birds and mollusks. According to Dias (2012), the subsistence strategies remained stable, being maintained throughout at least 6000 years $^{6}$.

It also should be taken into account that, although the total replacement of darts by the arrows occurred in many places in America, there are several studies in North America showing the co-existence of the two technologies (i.e., the persistence of the use of darts) after the introduction of the bow and arrow over a fairly long period (Aikens 1978, Chatters et al. 1995, Fawcett 1998, Hall 1997, Heizer 1938, Kennett et al. 2013, Massey 1961, Nassaney and Pyle 1999, Railey 2010, Shott 1996, 1997, Swanton 1938, VanPool 2006, Walde

${ }^{6}$ There are no available studies on faunal remains for Tunas, Pedro F. Schmitz, Alice Boer, and Morro da Flecha 1.
2013, Yerkes and Pecora 1990, Yohe II 1998, but see Whittaker 2012 for a discussion on VanPool 2006), especially in marginal areas (Kellar 1955). For example, it is known that the dart was widely used in the context of war by the Mexica (Aztecs) and the Maya, even after the introduction of the bow and arrow (VanPool 2006, Webster 2000). Likewise, several ethnographic examples of use of both the bow and the atlatl in North America (Artic groups), Central, and South America were reported, with groups showing variable preference of one over the other, but knowing how to build both (e.g., Bennett 1946, Lothrop 1948, Steward 1948, Stout 1948). The same situation is described by ethnographers for several Brazilian groups such as the Jivaro in the $16^{\text {th }}$ century (Stirling 1938), the Ticuna (Nimuendajú 1948), the Trumai (Murphy and Quain 1955), and Warao (Wilbert 1980).

Thus, the contemporary use of the two systems shows that darts and arrows may be considered complementary technologies (Erwin et al. 2005). In some cases, it is possible that the existence of darts after the advent of the bow and arrow is a manifestation of "sleeping" technologies (Borrero 2011), i.e., technologies that are not used intensely for a given group, but are still known and may, depending on the situation, be used. Non "utilitarian" use of atlatls has been reported by ethnographers for various groups in the Brazilian territory that use (or used in the recent past) atlatls for purposes of competition among groups. This was the case of the Karajá from Araguaia (Ehrenreich 1948), who had their "Game of Tapirapé" (Baldus 1970), and the following groups from Xingu, who have the Yawari, or spearthrowing ceremony (Galvão 1979): the Kamayurá (Menezes Bastos 2004), the Wauja (Barcelos Neto 2004), the Auety, and the Trumai (Murphy and Quain 1955, Steinen 1940). Similar examples are found in North America (VanPool 2006). Another possibility that could explain the lack of a consistent substitution of the atlatl by the bow 
the would be an initial introduction, the loss and a later re-introduction of bow and arrow technology, as observed in the Late Paleolithic in Southern Scandinavia (Riede 2009). Therefore, we see no reason to always expect the complete substitution of the bow for the atlatl, and its adoption seems to be context-dependent. Although our results are not conclusive, they suggest the co-existence of two different technologies represented in some of our analyzed sites.

Finally, the poor preservation of organic remains not only hinder the discovery of important parts of the two systems (shafts, bows, and atlatls), but may also prevent the understanding of the early stages of bow and arrow technology in cases in which there are points made of perishable materials. This is the case of points made of wood or, as in the case of the oldest arrowheads in southern Peru and northern Chile, made with cactus thorns and bone fragments (Owen 1998).

\section{CONCLUSION}

Although the techniques used here to infer the presence of the dart or arrow technology in archaeological sites in southeastern and southern Brazil must be understood within their limitations, our results strongly suggest the presence of small points whose morphology can be considered compatible with the system of the bow and arrow. Interestingly, the oldest archaeological site from our sample (Tunas rockshelter), dated from the early Holocene, presented higher proportions of points classified as "arrows", suggesting the potential presence of this technology in very ancient times and much earlier than most dates proposed for the origin of the bow and arrow in other parts of the Americas.

While these analyzed points are considered projectile points, for now, one cannot be sure about their use, since no research has been done on the subject. Thus, we cannot exclude the possibility that some of these specimens may have been used in other ways (awl, knife, spear, ritual use, etc.). As Erlandson et al. (2014) remark, the interpretation of projectile point systems based solely on size or morphology of points must be carefully considered, especially when no further information on cultural contexts, faunal contexts, use wear, among other information, is available.

Be that as it may, we can advance an argument that, from the statistical point of view, there is a fair probability that the bow and arrow technology in eastern South America is much older than previously thought, and in fact contradicts the expected trend of north-to-south spread of the bow and arrow. It is worth beginning to consider the possibility of the independent invention of the bow and arrow technology during the Pleistocene / Holocene boundary in eastern South America. This would not be the first such case, since it probably also occurred in the Old World (Shea 2006).

Future studies that seek to improve or modify the techniques applied here, as well as studies that would include either a larger sample of the archaeological sites analyzed here or other archaeological sites not included in this work could complement or contrast the results obtained so far. Information about the stratigraphic position of excavated projectile points, as well as dating of many archaeological levels from the same site may also help refine our understanding of the origins of the use of different projectile point technology in southeastern and southern Brazil during prehistory.

\section{ACKNOWLEDGMENTS}

Thanks are due to everyone who contributed to this research through the generous access to the collections: Adriana Schmidt Dias (UFRGS), Igor Chmyz (Centro de Estudos e Pesquisas Arqueológicas - CEPA / UFPR), Jefferson Dias (Museu Arqueológico do Rio Grande do Sul Marsul), João Boer (in memoriam), Pedro Ignácio Schmitz (Instituto Anchietano de Pesquisas - IAP / Universidade do Vale do Rio dos Sinos - Unisinos), 
and Sergio Klamt (CEPA / Universidade de Santa Cruz do Sul - UNISC). We would also like to thank the editor and the two anonymous reviewers for their helpful and constructive comments that greatly contributed to improving the final version of the article. This research was financially supported by Conselho Nacional de Desenvolvimento Científico e Tecnológico (CNPq, 159776/2010-4, 443169/2014-4 and 303566/2014-0) and Fundação de Amparo à Pesquisa do Estado de São Paulo (FAPESP, 2010/06453-9 and 2013/13794-5).

\section{RESUMO}

Pontas bifaciais líticas são muito comuns nas regiões sul e sudeste do território brasileiro. Essas pontas, datadas desde o começo do Holoceno até o fim desse período, não têm sido estudadas em termos de seus sistemas de propulsão. Dadas as características do arco e flecha e comparando-as com dardo e propulsor, verifica-se que há diferenças importantes no tamanho e na massa de pontas de flecha e pontas de dardo. Aplicando-se as técnicas propostas por Shott (1997), Bradbury (1997), Fenenga (1953), Hughes (1998) e Hildebrandt e King (2012) a espécimes escavados em oito sítios datados do início até o fim do Holoceno, este trabalho tem como objetivo apresentar resultados preliminares para uma melhor compreensão da presença potencial de dardos e flechas nas regiões sul e sudeste do Brasil. Houve uma variação nos resultados de acordo com a aplicação de diferentes técnicas. Pelo menos um conjunto de pontas, datado do início do Holoceno, apresentou uma proporção relativamente alta de espécimes classificados como flechas, indicando a presença de pontas que poderiam ser usadas como flechas.

Palavras-chave: arqueologia, flecha, propulsor, arco, dardo, Tradição Umbu.

\section{REFERENCES}

AHLER SA. 1971. Projectile Point Form and Function at Rodgers Rockshelter, Missouri. Columbia: Missouri Archaeological Society.

AIKENS CM. 1978. The Far West. In: Jennings JD (Ed), Ancient Native Americans, San Francisco: W.H. Freeman and Company, p. 131-181.
AliX C, HARE PG, ANDREWS TD AND MACKAY G. 2012. A thousand years of lost hunting arrows: Wood analysis of ice patch remains in northwestern Canada. Arctic 65: 95-117.

AMES KM, FULD KA AND DAVIS S. 2010. Dart and arrow points on the Columbia Plateau of Western North America. Am Antiquity 75: 287-325.

ANDREFSKY JR W. 1994. Raw-material availability and the organization of technology. Am Antiquity 59: 21-34.

ANDREWS TD, MACKAY G AND ANDREW L. 2012. Archaeological investigations of alpine ice patches in the Selwyn Mountains, Northwest Territories, Canada. Artic: $1-21$.

AOYAMA K. 2005. Classic Maya Warfare and Weapons: Spear, dart, and arrow points of Aguateca and Copan. Ancient Mesoam 16: 291-304.

Araujo AGM. 2012. Projeto "A Ocupação Paleoíndia no Estado de São Paulo: uma Abordagem Geoarqueológica" Final Report (FAPESP). São Paulo: MAE-USP, 222 p.

ARRIAZA B. 1995. Chinchorro Bioarchaeology: Chronology and Mummy Seriation. Lat Am Antiquity 6: 35-55.

ARRIAZA BT, STANDEN VG, CASSMAN V AND SANTORO CM. 2008. Chinchorro Culture: Pioneers of the Coast of the Atacama Desert. In: Silverman H and Isbell WH (Eds), Handbook of South American Archaeology, New York: Springer, p. 45-58.

BACHECHI L, FABBRI P-F AND MALlEGNi F. 1997. An Arrow-Caused Lesion in a Late Upper Paleolithic Human Pelvis. Curr Antropol 38: 135-140.

BALdus H. 1970. The Tapirapé: A Tupi Tribe of Central Brazil. Rev Arq Munic, p. 96-105, 107-124, 127.

Barcelos Neto A. 2004. Processo Criativo e Apreciação Estética no Grafismo Wauja. Cad Campo 13: 87-108.

BARTON H, PIPER PJ, RABETt R AND REEDS I. 2009. Composite hunting technologies from the Terminal Pleistocene and Early Holocene, Niah Cave, Borneo. J Archaeol Sci 36: 1708-1714.

BENNETT WC. 1946. The Andean Highlands: An Introduction. In: Steward J (Ed), Handbook of South American Indians: The Andean Civilizations: Smithsonian Institution, Bureau of American Ethnology, p. 1-60.

Bergman CA, MCEwen E AND Miller R. 1988. Experimental Archery: Projectile Velocities and Comparison of Bow Performances. Antiquity 62: 658-670.

BetTinger RL. 2013. Effects of the Bow on Social Organization in Western North America. Evol Anthropol 22: $118-123$.

BIRD JB. 1943. Excavations in Northern Chile. Anthropol Pap Am Mus 27.

BIRD JB. 1946. The Cultural Sequence of the North Chilean Coast. In: Steward JH (Ed), Handbook of South American Indians, Washington, D.C., p. 587-594. 
BITTMANN B AND MunizAGA JR. 1979. El Arco en América: Evidencia Temprana y Directa de la Cultura Chinchorro (norte de Chile). Indiana 5: 229-251.

BITTMANN B AND MunizAGA JR. 1984. Comments on a Double Mummy Containing a Spear Thrower, in the "Anke Nielsen Collection", Iquique, Northern Chile. Indiana 9: 383-419.

BLITZ J. 1988. Adoption of the Bow in Prehistoric North America. N Am Archaeol 9: 123-145.

BORRERO LA. 2011. The Theory of Evolution, Other Theories, and the Process of Human Colonization of America. Evolution: Education and Outreach 4: 218-222.

BRADBURY AP. 1997. The Bow and Arrow in the Eastern Woodlands: Evidence for an Archaic Origin. N Am Archaeol 18: 207-233.

BROCHADO JP AND SCHMITZ PI. 1972-1973. Aleros y cuevas com petroglifos e industria lítica de la escarpa del Planalto Meridional en Rio Grande do Sul, Brasil. An Arqueol Etnol (Mendoza) XXVII-XXVIII: 39-66.

BROWNE J. 1938. Antiquity of the bow. Am Antiquity 3: 358359.

BRUECHERT LW. 1998. Mummy Burial of the Muisca Empire. The Atlatl 11.

BUTLER WB. 1975. The Atlatl: The Physics of Function and Performance. Plains Anthropol 20: 105-110.

CAPITAN L. 1911. Une arme des anciens Péruviens: l'estolica; son identlfication par l'iconographie céramique. Cr Acad Inscr Belle 55e année: 407-410.

CARDillo M. 2009. Temporal trends in the morphometric variation of the lithic projectile points during the Middle Holocene of Southern Andes (Puna region) - a coevolutionary approach. In: Muscio HJ and López GEJ (Eds), Theoretical and Methodological Issues in Evolutionary Archaeology: Toward an unified Darwinian paradigm, Oxford: Archaeopress, p. 13-20.

CARDillo M AND AlBerti J. 2014. The evolution of projectile points and technical systems: A case from Northern Patagonian coast (Argentina). J Archaeol Sci Reports 2: 612-623.

CAsanova E. 1944. Uma estolica de La Puna Jujeña. Relaciones de la Sociedad Argentina de Antropología 4: 115-132.

Cattelain P. 1997. Hunting during the Upper Paleolithic: Bow, Spearthrower, or Both? In: Knecht H (Ed), Projectile Technology, New York: Plenum, p. 213-240.

CHARD CS. 1955. Eskimo archaeology in Siberia. Southwest J Anthrop: 150-177.

Charlin J AND GOnZÁLEZ-JosÉ R. 2012. Size and Shape Variation in Late Holocene Projectile Points of Southern Patagonia: A Geometric Morphometric Study. Am Antiquity 77: 221-242.

CHATTERS JC. 2001. Ancient Encounters: Kennewick Man and the First Americans. New York: Simon and Schuster, 290 p.
Chatters JC, CAMPBELl SK, SMith GD AND MINTHORN JR PE. 1995. Bison Procurement in the Far West: A 2,100-Year-Old Kill Site on the Columbia Plateau. Am Antiquity 60: 751-763.

CHÊNG TÊ-K'UN. 1974. The Prehistory of China. T'oung Pao $1-11$.

Chmyz I, SGanzerla EM, Volcov JE, Bora E AND CECCON RS. 2008. A arqueologia da área da LT 750kV Ivaiporã-Itaberá III, Paraná - São Paulo. Arqueologia (Revista do CEPA) 5: 1-305.

Christenson AL. 1986. Projectile Point Size and Projectile Aerodynamics: An Exploratory Study. Plains Anthropol 31: 109-128.

Ciofalo AJ. 2012. Maya Use and Prevalence of the Atlatl: Projectile Point Classification Function Analysis from Chichén Itzá, Tikal, and Caracol. University of Central Florida, $91 \mathrm{p}$.

CoBo B. 1890-1893 [1953]. Historia del Nuevo Mundo (Publicada por primera vez con notas y otras ilustraciones de D. Marcos Jiménez de la Espada). Sevilla: Pubi Sociedad de Bibliófilos Andaluces.

COCKRELl WA AND MURPHY L. 1978. Pleistocene Man in Florida. Archaeology of Eastern North America 6: 1-13.

Collins MB. 1975. Lithic Technology as a Means of Processual Inference. In: Swanson E (Ed), Lithic Technology, Making and Using Stone Tools, The Hague: Mouton, p. 15-34.

CORLISS DW. 1972. Neck Width of Projectile Points. An Index of Culture Continuitv and Change. Occasional Papers No 29, Pocatello: Idaho State University Museum.

CRESSMAN LS. 1977. Prehistory of the Far West: homes of vanished peoples. Salt Lake City: University of Utah Press, $248 \mathrm{p}$.

DE LOBERA PM, DE ESCOBAR B AND ECHEVARRÍA JU. 1970. Crónica del reino de Chile. Editorial Universitaria.

DE SouzA PH. 2004. Tecnologías de proyectil durante los períodos Arcaico y Formativo en el Loa Superior (Norte de Chile): a partir del análisis de puntas líticas. Chungara Volumen Especial: Simposio Perspectivas Teóricas y Metodológicas en los Estudios Líticos, p. 61-76.

DIAS AS. 2012. Hunter-gatherer occupation of south Brazilian Atlantic Forest: Paleoenvironment and archaeology. Quatern Int 256: 12-18.

DICKSON DB. 1985. The Atlatl Assessed: A Review of Recent Anthropological Approaches to Prehistoric North American Weaponry. Bulletin of the Texas Archaeological Society 56: 1-36.

DIXON JE. 1999. Bones, Boats, and Bison: Archeology and the First Colonization of Western North America. Albuquerque: University of New Mexico Press, 333 p.

EHRENREICH P. 1949. Contribuições para a Etnologia do Brasil. Rev Mus Paul. Nova Série 2: 7-135. 
ERLANDSON J, WATTS JL AND JEW NP. 2014. Darts, Arrows, and Archaeologists: Distinguishing Dart and Arrow Points in the Archaeological Record. Am Antiquity 79: 162-169.

ERWIN JC, HOLLY JR DH, Hull SH AND RAST TL. 2005. Form and Function of Projectile Points and the Trajectory of Newfoundland Prehistory. Canadian Journal of Archaeology 29: 46-67.

EVANS OF. 1957. Probable use of stone projectile points. Am Antiquity 23: 83-84.

EVANS OF. 1959. The Development of the Atlatl and the Bow. Bulletin of the Texas Archaeological Society 30: 159-162.

FARMER MF. 1994. The Origins of Weapons Systems. Curr Antropol 35: 679-681.

FAWCETT JR WB. 1998. Chronology and projectile point neck-width: An Idaho example. N Am Archaeol 19: 59-85.

FAWCETT JR WB AND KORNFELD M. 1980. Projectile point neck-width variability and chronology on the Plains. Wyoming Contributions to Anthropology 2: 66-79.

FENENGA F. 1953. The weights of chipped stone points: A clue to their functions. Southwest J Anthrop 9: 309-323.

FERNÁNDEZ DISTEL AA. 1977. Nuevos hallazgos de estólicas en el borde de la puna jujeña (Argentina), y reactualización del problema según recientes investigaciones en los Andes Meridionales. In: VII Congreso de Arqueología de Chile, 1977 Altos Vilches, Talca, Chile, p. 132-165.

FOCACCI G. 1974. Excavaciones en el cementerio Playa Miller-7 (Arica). Chungara 3: 23-74.

FOCACCI G AND CHACÓN S. 1989. Excavaciones arqueológicas en los faldeos del Morro de Arica: sitios Morro 1/6 y 2/2. Chungara 22: 15-62.

Franco NV, CASTRO A, CARDILlO M AND CHARLIN J. 2009. La importancia de las variables morfológicas, métricas y de microdesgaste para evaluar las diferencias en diseños de puntas de proyectil bifaciales pedunculadas: un ejemplo del Sur de Patagonia continental. Magallania 37: 99-112.

FREIDEL DA. 1986. The Mesoamerican World. Lat Am Res Rev 21: 231-241.

GALVÃo E. 1979. O uso do propulsor entre as tribos do Alto Xingu. In: Galvão E (Ed), Encontro de Sociedades: Índios e Brancos no Brasil, Rio de Janeiro: Paz e Terra, p. 39-56.

GAMBIER M AND SACCHERO P. 1969. Excavaciones en Los Morrillos de Ansilta. Trabajos preliminares. Actas del V Congreso Nacional de Arqueología, 1969. La Serena, Chile, p. 389-395.

GARCILASO DE LA VEGA EI. 1960-1963. Comentarios Reales de los Incas, edición y estudio preliminar del P. Carmelo Saenz de Santa María, S.I. Biblioteca de Autores Españoles, Madrid: Atlas, Tomo 1, 544 p.

GEIB PR. 1990. A Basketmaker II Wooden Tool Cache from Lower Glen Canyon. Kiva 55: 265-277.

GREAVES RD. 1997. Hunting and multifunctional use of bows and arrows: Ethnoarchaeology of Technological
Organization among Pumé Hunters of Venezuela. In: Knecht H (Ed), Projectile technology, New York: Plenum, p. 287-320.

HALL RL. 1997. An Archaeology of the Soul: North American Indian Belief and Ritual. Urbana: University of Illinois Press, $222 \mathrm{p}$.

HAMILTON TM. 1982. Native American Bows. Columbia: Missouri Archaeological Society Special Publication No. 5.

HARE PG, THOMAS CD, TOPPER TN AND GOTTHARDT RM. 2012. The archaeology of Yukon ice patches: New artifacts, observations, and insights. Arctic 118-135.

HARPER C AND ANDREFSKY JR W. 2008. Exploring the Dart and Arrow Dilemma: Retouch Indices as Functional Determinants. In: Andrefsky Jr W (Ed), Lithic Technology: Measures of Production, Use and Curation, Cambridge: Cambridge University Press, p. 175-194.

HASSIG R. 1988. Aztec Warfare: Imperial Expansion and Political Control. The Civilization of the American Indian Series, Norman: University of Oklahoma Press, 404 p.

HASSIG R. 1992. War and Society in Ancient Mesoamerica. Berkeley: University of California Press, 337 p.

HEIZER RF. 1938. An Inquiry into the Status of the Santa Barbara Spear-Thrower. Am Antiquity 4: 137-141.

HEIZER RF. 1951. Preliminary Report on the Leonard Rockshelter Site, Pershing County, Nevada. Am Antiquity 17: 89-98.

HESTER TR. 1973. Chronological Ordering of Great Basin Prehistory. Contributions to the University of California Archaeological Research Facility, No 17, Berkeley.

HILDEBRANDT WR AND KING JH. 2012. Distinguishing between Darts and Arrows in the Archaeological Record: Implications for Technological Change in the American West. Am Antiquity 77: 789-799.

HILL MW. 1948. The Atlatl or Throwing Stick: A Recent Study of Atlatls in Use with Darts of Various Sizes. Tenn Archaeologist 4: 37-44.

HOFFMAN CM. 1985. Projectile point maintenance and typology: Assessment with factor analysis and canonical correlation. In: Carr C (Ed), For Concordance in Archaeological Analysis: Bridging Data Structure, Quantitative Technique, and Theory, Kansas City, Mo. and Fayetteville: Westport Publishers, p. 566-612.

Hostnig R. 2003. Macusani, Repositorio de Arte Rupestre Milenario en la Cordillera de Carabaya, Puno - Perú. Boletim SIARB 17: 17-35.

Hostnig R. sinus data. Pinturas rupestres arcaicas de la provincia de Espinar, Cusco. Rupestreweb. Available: http://www.rupestreweb.info/espinar.html.

HrDLICKA D. 2003. How Hard Does It Hit? A Revised Study of Atlatl and Dart Ballistics. The Atlatl 16: 15-18.

HugHES S. 1998. Getting to the Point: Evolutionary Change in Prehistoric Weaponry. J Archaeol Method Th 1: 345-406. 
HUTCHINGS WK AND BRUCHERT LW. 1997. Spearthrower Performance: Ethnographic and Experimental Research. Antiquity 71: 890-897.

KAY M. 1996. Microwear Analysis of Some Clovis and Experimental Chipped Stone Tools. In: Odell G (Ed), Stone Tools: Theoretical Insights into Human Prehistory, New York: Plenum Press, p. 315-344.

KeLlar JH. 1955. The Atlatl in North America. Prehistory Research Series, n. 3, Indiana: Indiana Historical Society, p. 280-352.

KENNETT DJ, LAMBERT PM, JOHNSON JR AND CULLETON BJ. 2013. Sociopolitical Effects of Bow and Arrow Technology in Prehistoric Coastal California. Evol Anthropol 22: 124-132.

LAHREN L AND BONNICHSEN R. 1974. Bone Foreshafts from a Clovis Burial in Southwestern Montana. Science 186: $147-150$

LANSAC JP. 2001. Discussion d'un cadre chronologique pour l'utilization du propulseur et de l'arc. MA thesis, University of Bordeaux.

LAS CASAS BD. 1892. De las antiguas gentes del Perú. Colección de Libros Españoles Raros o Curiosos, 21, Madrid, 368 p.

LATCHAM RE. 1938. Arqueología de la región atacameña. Santiago: Prensas de la Universidade de Chile.

LAVAllÉE D. 2000. The First South Americans: The Peopling of a Continent from the Earliest Evidence to High Culture. Salt Lake City: University of Utah Press, 260 p.

LEBLANC S. 1999. Prehistoric Warfare in the American Southwest. Salt Lake City: University of Utah Press, 400 p.

LEBLANC S. 2003. Warfare in the American Southwest and Mesoamerica. In: Brown MK and Stanton TW (Eds), Ancient Mesoamerican Warfare, New York: Altamira Press, p. 265-286.

LEBLANC SA. 1997. Modeling Warfare in Southwestern Prehistory. N Am Archaeol 18: 235-276.

LESSA A AND MENDONÇA DE SOUZA S. 2003. Violence in the Atacama Desert during the Tiwanaku Period: Social Tension? Int J Osteoarchaeol 14: 374-388.

LOMBARD M, PARSONS I AND VAN DER RYST MM. 2004. Middle Stone Age lithic point experimentation for macrofracture and residue analyses: the process and preliminary results with reference to Sibudu Cave points. S Afr J Sci 100: 159-166.

LOMBARD M AND PHILLIPSON L. 2010. Indications of bow and stone-tipped arrow use 64,000 years ago in KwaZuluNatal, South Africa. Antiquity 84: 635-648.

LOTHROP SK. 1948. The tribes West and South of the Panama Canal. In: Steward J (Ed), Handbook of South American Indians: The Circum-Caribbean Tribes: Smithsonian Institution, Bureau of American Ethnology, p. 253-256.
LYMAN RL, VANPOOL TL AND O'BRIEN MJ. 2008. Variation in North American dart points and arrow points when one or both are present. J Archaeol Sci 35: 2805-2812.

LYMAN RL, VANPOOL TL AND O'BRIEN MJ. 2009. The diversity of North American projectile-point types, before and after the bow and arrow. J Anthropol Archaeol 28: $1-13$.

MARRINER HA. 2002. Dart-thrower use depicted in Colombian rock art. International Newsletter on Rock Art, p. 25-28.

MASCHNER H AND MASON OK. 2013. The Bow and Arrow in Northern North America. Evol Anthropol 22: 133-138.

MASON OT. 1885. Throwing Sticks in the National Museum. Smithsonian Institution Annual Report for 1884, part 2, Washington, D. C.: Government Printing Office, p. 279290.

MASSEY WC. 1961. The Survival of the Dart-Thrower on the Peninsula of Baja California. Southwest J Anthrop 17: 8192.

MAU C. 1963. Experiments with the Spear Thrower. The New York State Archaeological Association Bulletin 29: 1-13.

Menezes BAstos RJD. 2004. The Yawari Ritual of the Kamayurá: A Xinguano Epic. In: Kuss M (Ed), Music in Latin American and the Caribbean: An Encyclopedic History Volume 1: Performing Beliefs: Indigenous Peoples of South America, Central America, and Mexico, Austin: University of Texas Press, p. 77-99.

MENTZ RIBEIRO PA, KLAMT SC, BUCHAIM JJS AND RIBEIRO CT. 1989. Levantamentos arqueológicos na encosta do planalto entre o vale dos rios Taquari e Caí, RS, Brasil. Revista do CEPA (Santa Cruz do Sul) 16: 49-89.

MENTZ RIBEIRO PA AND RIBEIRO CT. 1999. Escavações Arqueológicas no Sítio RS-TQ-58: Montenegro, RS, Brasil. Série Documento (Editora da FURG) 10: 1-86.

MÉTRAUX A 1949. Weapons. In: Steward JH (Ed), Handbook of South American Indians, Washington D.C., p. 229-263.

MILDNER MP. 1974. Descriptive and Distributional Notes on Atlatls and Atlatl Weights in the Great Basin. In: Hester TR, Mildner MP and Spencer L (Eds), Great Basin Atlatl Studies, Ramona, CA: Ballena Press, p. 7-17.

Miller ET. 1967. Pesquisas Arqueológicas Efetuadas no Nordeste do Rio Grande do Sul. In: Simões M (Ed), Programa Nacional de Pesquisas Arqueológicas: Resultados Preliminares do Primeiro Ano (1965-1966): Publicações Avulsas do Museu Paranaense Emílio Goeldi 6: 15-38.

MiLleR ET. 1974. Pesquisas Arqueológicas em Abrigos-sobRocha no Nordeste do Rio Grande do Sul. In: Simões M (Ed), Programa Nacional de Pesquisas Arqueológicas: Resultados Preliminares do Quinto Ano (1969-1970): Publicações Avulsas do Museu Paranaense Emílio Goeldi 26: 11-24.

MILLER II MJ. 2009. “A Tale of Two Weapons”: Late Holocene Hunting Technology in North Central Texas. Master of Science, University of North Texas, $170 \mathrm{p}$. 
MORRISEY G. 2009. Tools and Change: The Shift from Atlatl to Bow on the British Columbia Plateau. Master of Arts, Simon Fraser University, $195 \mathrm{p}$.

MORSE PA AND MORSE DF. 1990. The Zebree Site: An Emerged Early Mississippian Expression in Northeast Arkansas. In: Smith B (Ed), The Mississippian Emergence, Washington, D. C.: Smithsonian Institution Press, p. 51-66.

MunizAGA C. 1964. Nota sobre una estólica y una estatuilla antropomorfa supuestamente vinculadas al complejo precerámico de la costa de Arica (Chile). Revista Universitaria (Santiago) 49: 169-172.

MuÑOZ I, RochA R AND CHACÓN S. 1991. Camarones 15: Asentamiento de Pescadores Correspondiente al Periodo Arcaico y Formativo en el Extremo Norte de Chile. Actas del XI Congreso Nacional de Arqueología Chilena, vol. II, Santiago, Museo Nacional de Historia Natural / Sociedad Chilena de Arqueología.

MURPHY RF AND QUAIN BH. 1955. The Trumaí Indians of Central Brazil. New York: Locust Vally, 108 p.

NAKAZAWA Y, IWASE A, AKAI F AND IZUHO M. 2011. Human responses to the Younger Dryas in Japan. Quatern Int 242: 416-433.

NASSANEY MS AND PYLE K. 1999. The adoption of the bow and arrow in eastern North America: A view from central Arkansas. Am Antiquity 64: 243-263.

NimuendAJÚ C. 1948. The Tucuna: habitat, history, and language. In: Steward JH (Ed), Handbook of South American Indians, Washington D.C., p. 713-725.

NúÑEZ AL. 1963. En torno a los propulsores prehispánicos del Norte de Chile. Boletín de la Universidad de Chile 44: 4-8.

NúÑEZ AL. 1992. Ocupación arcaica en la Puna de Atacama: Secuencia, movilidad y cambio. In: Meggers BJ (Ed), Prehistoria sudamericana: Nuevas Perspectivas, Washington: Taraxacum, p. 283-307.

O'CONNELL AL AND GARDNER EB. 1972. Understanding the Scientific Bases of Human Movement. Baltimore: Waverly Press.

ODELL GH AND COWAN F. 1986. Experiments with Spears and Arrows on Animal Targets. J Field Archaeol 13: 195 212.

OKumura M And Araujo AGM. 2013. Pontas Bifaciais no Brasil Meridional: Caracterização Estatística das Formas e suas Implicações Culturais. Revista do Museu de Arqueologia e Etnologia (USP) 23: 111-127.

OKUMURA M AND ARAUJO AGM. 2014. Long-term cultural stability in hunter-gatherers: a case study using traditional and geometric morphometric analysis of lithic stemmed bifacial points from Southern Brazil. J Archaeol Sci 45: 59-71.

OWEN B. 1998. Bows and Spearthrowers in Southern Peru and Northern Chile: Evidence, Dating, and Why it Matters. In: Paper presented at the $63^{\text {rd }}$ Annual Meeting of the Society for American Archaeology, 1998 Seattle, WA.
PITT RIVERS AHL-F. 1906. The Evolution of Culture and Other Essays. Oxford: Clarendon Press, 254 p.

PRIETO A. 1989-1990. Cazadores tardíos en la zona fronteriza del paralelo $52^{\circ}$ sur. El alero Peggy Bird. Anales del Instituto de la Patagonia Serie Cs. Sc. 19: 73-85.

PRINS HEL. 2010. The Atlatl as Combat Weapon in $17^{\text {th }}$ Century Amazonia: Tapuya Indian Warriors in Dutch Colonial Brazil. The Atlatl 23: 1-10.

Prous A. 1991a. Arqueologia brasileira. Brasília: Universidade de Brasília, $605 \mathrm{p}$.

PROUS A. 1991b. Alimentação e "arte" rupestre: nota sobre alguns grafismos pré-históricos brasileiros. Revista de Arqueologia 6: 1-15.

Prous A AND BAETA AM. 1992-1993. Elementos de cronologia, descrição de atributos e tipologia. Arquivos do Museu de História Natural da UFMG 13: 241-295.

RATTO N. 1992. Análisis funcional de las puntas de proyectil liticas de sitios del sudeste de la Isla Grande de Tierra del Fuego. Arqueología ICA, p. 151-178.

RATTO N. 1994. Funcionalidad versus adscripción cultural: cabezales líticos de la margen norte del estrecho de Magallanes. In: Lanata J1 and Borrero LA (Eds), Arqueología de Cazadores-recolectores Límites, casos y aperturas Arqueología Contemporánea 5, Buenos Aires, p. 105-120.

RAUSING G. 1967. The bow: some notes on its origin and development. Acta Archaeologica Lundensia (Papers of the Lunds Universitets Historiska Museum), series in 80 no 6, Bonn A. R. / Lund: Rudolf Habelt Verlag / CWK Gleerups Förlag, 189 p.

RAILEY JA. 2010. Reduced Mobility or the Bow and Arrow? Another Look at "Expedient" Technologies and Sedentism. Am Antiquity 75: 259-286.

RAYMOND A. 1986. Experiments in the Function and Performance of the Weighted Atlatl. World Archaeol 18: 153-177.

RECKIN R. 2013. Ice Patch Archaeology in Global Perspective: Archaeological Discoveries from Alpine Ice Patches Worldwide and Their Relationship with Paleoclimates. J World Prehist 26: 323-385.

REED PF AND GEIB PR. 2013. Sedentism, Social Change, Warfare, and the Bow in the Ancient Pueblo Southwest. Evol Anthropol 22: 103-110.

RIEDE F. 2009. The loss and re-introduction of bow-and-arrow technology: a case study from the Northern European Late Paleolithic. Lithic Technology 34: 27-45.

RIVERA MA. 1975. Una hipótesis sobre movimientos poblacionales altiplánicos en las costas del Norte de Chile. Chungara 5: 7-31.

RosA A AND JACOBUS A. 2010. Registro de mamíferos em sítios arqueológicos do Rio Grande do Sul, Brasil. In: Ribeiro AM, Bauerman S and Scherer C (Eds), Quaternário do Rio Grande do Sul: Integrando Conhecimentos, 
Porto Alegre: Monografias da Sociedade Brasileira de Paleontologia, p. 233-241.

RoWE JH. 1946. Inca Culture at the Time of Spanish Conquest. In: Steward JH (Ed), Handbook of South American Indians, Washington, D.C.: US Government Printing Office, p. 183-330.

SAHLE Y, HUTCHINGS WK, BRAUN DR, SEALY JC, MORGAN LE, Negash A And Atnafu B. 2013. Earliest StoneTipped Projectiles from the Ethiopian Rift Date to >279,000 Years Ago. PloS One 8: e78092.

SCHALK RF AND OLSON DL. 1983. Archaeological Testing of the Prehistoric Site at Lyons Ferry. In: Schalk RF (Ed), Cultural Resource Investigations for the Lyons Ferry Fish Hatchery Project, near Lyons Ferry, Washington, Pullman: Project Report No. 8, Laboratory of Archaeology and History, Washington State University, p. 141-178.

SCHMITZ PI. 1987. Prehistoric hunters and gatherers of Brazil. J World Prehist 1: 53-126.

SCHMITz PI. 2006. Sítio Pedro Fridolino Schmitz, Bom Princípio, RS. Número do sítio RS 217. Anais do V encontro do Núcleo Regional Sul da Sociedade de Arqueologia Brasileira - SAB/Sul, 2006. Rio Grande, RS.

SHEA JJ. 2006. The origins of lithic projectile point technology: evidence from Africa, the Levant, and Europe. J Archaeol Sci 33: 823-846.

SHOTT MJ. 1993. Spears, Darts, and Arrows: Late Woodland Hunting Techniques in the Upper Ohio Valley. Am Antiquity 58: 425-443.

SHOTT MJ. 1996. Innovation and selection in prehistory: a case study from the American bottom. In: Odell GH (Ed), Stone Tools: Theoretical Insights into Human Prehistory, New York: Plenum Press, p. 279-309.

ShotT MJ. 1997. Stones and Shafts Redux: The Metric Discrimination of Chipped-Stone Dart and Arrow Points. Am Antiquity 62: 86-101.

STEINEN KVD. 1940. Entre os aborígenes do Brasil Central. Separata da Revista do Arquivo. São Paulo: Departamento de Cultura, n. XXXIV e LVIII: 179-206.

STEWARD J. 1948. The Circum-Caribean Tribes: An Introduction. In: Steward J (Ed), Handbook of South American Indians: The Circum-Caribbean Tribes: Smithsonian Institution, Bureau of American Ethnology, p. 1-41.

STIRLING MW. 1938. Historical and Ethnographical Material on the Jivaro Indians. Washington: Smithsonian Institution, Bureau of American Ethnology, Bulletin 117, Government Printing Office, $148 \mathrm{p}$.

STOUT DB. 1948. The Choco. In: Steward J (Ed), Handbook of South American Indians: The Circum-Caribbean Tribes: Smithsonian Institution, Bureau of American Ethnology, p. 269-276.

SWANTON JR. 1938. A Historic Use of the Spear-thrower in Southeastern North America. Am Antiquity 3: 356-358.

TAYLOR RE. 2009. Six Decades of Radiocarbon Dating in New World Archaeology. Radiocarbon 51: 173-212.
THOMAS DH. 1978. Arrowheads and atlatl darts: how the stones got the shaft. Am Antiquity 43: 461-472.

TOMKA SA. 2013. The Adoption of the Bow and Arrow: A Model Based on Experimental Performance Characteristics. Am Antiquity 78: 553-569.

TORRES-ROUFF C AND KNUDSON KJ. 2007. Examining the life history of an individual from Solcor 3, San Pedro de Atacama: combining bioarchaeology and archaeological chemistry. Chungara 39: 235-257.

UhLe M. 1909. Peruvian Throwing Sticks. Am Anthropol 11: 624-627.

UHLE M. 1917. Los aborígenes de Arica. Publicaciones del Museo de Etnología y Antropología 1: 151-176.

UHLE M. 1919. La arqueología de Arica y Tacna. Boletín de la Sociedad Ecuatoriana de Estudios Históricos Americanos 3: $1-48$.

UHLE M. 1922. Fundamentos Etnicos y Arqueología de Arica y Tacna. Segunda Edición ed, Quito: Imprenta de la Universidad Central.

UHLE M. 1974. Los aborígenes de Arica y el hombre americano. Chungara 3: 13-21.

VANPoOL TL. 2006. The Survival of Archaic Technology in an Agricultural World: How the Atlatl and Dart Endured in the North American Southwest. Kiva 71: 429-452.

VANPOOL TL AND O'BRIEN MJ. 2013. Sociopolitical complexity and the bow and arrow in the American Southwest. Evol Anthropol 22: 111-117.

VignATI MA. 1936. El uso del propulsor en el noroeste argentino. Notas del Museo de la Plata 1: 349-358.

WALDE D. 2013. The Bow and Cultural Complexity of the Canadian Plains. Evol Anthropol 22: 139-144.

Webster D. 2000. The Not so Peaceful Civilization: A Review of Maya War. J World Prehist 14: 65-119.

WEIDERHOLD JE, SHAFFER HJ AND PERRIN D. 2003. A Study of Two Ancient Bows from Trans-Pecos Texas. Bulletin of the Texas Archaeological Society 74: 89-101.

WENINGER B, JÖRIS O AND DANZEGLOCKE U. 2012. CalPal-2007. Cologne radiocarbon calibration, palaeoclimate research package. http://www.calpal.de/.

WESOLOWSKI V. 2000. A prática da horticultura entre os construtores de Sambaquis e acampamentos litorâneos da região da Baía de São Francisco, Santa Catarina: Uma abordagem bio-antropológica. MPhil, Universidade de São Paulo.

WHITTAKER JC. 2006. Atlatl Use on Moche Pottery of Ancient Peru. The Atlatl 19.

WHITTAKER JC. 2007. Late Survival of Atlatls in the American Southwest? The Atlatl 20: 10-12.

WhitTAKeR JC. 2010. Weapon Trials: The Atlatl and Experiments in Hunting Technology. In: Ferguson J (Ed), Designing Experimental Research in Archaeology: Examining Technology Through Production and Use, Boulder: University Press of Colorado p. 195-224. 
WHITTAKER JC. 2012. Ambiguous Endurance: Late Atlatls in the American Southwest? Kiva 78 1: 79-98.

WHITTAKER JC. 2013. Comparing Atlatls and Bows: Accuracy and Learning Curve. Ethnoarchaeology 5: 100-111.

WILBERT J. 1980. The Warao Indians of the Orinoco Delta. In: Wilbert J and Miguel L (Eds), Demographic and biological studies of the Warao Indians, Los Angeles: University of California, p. 3-9.

WILCOX DR AND HAAS J. 1994. The Scream of the Butterfly: Competition and Conflict in the Prehistoric Southwest. In: Gumerman GJ (Ed), Themes in Southwest Prehistory, Santa Fe: School of American Research, p. 211-238.

WILHELMSEN KH. 2001. Building the framework for an evolutionary explanation of projectile point variation: An example from the central Mississippi River valley. In:
Hunt TL, Lipo CP and Sterling SL (Eds), Posing Questions for a Scientific Archaeology, Westport, CT: Bergin and Garvey, p. 97-144.

YERKES RW AND PECORA AM. 1991. The Introduction of the Bow and Arrow. In: Niquette CM and Hughes MA (Eds), Late Woodland Archaeology at the Parkline Site (46PU99), Putnam County, West Virginia, Lexington, Kentucky: Cultural Resource Analysts, Inc., p. 95-106.

YOHE II RM. 1998. The introduction of the bow and arrow and lithic resource use at rose spring (CA-INY-372). Journal of California and Great Basin Anthropology 20: 26-52.

\section{SUPPLEMENTARY MATERIAL}

ARCHAEOLOGICAL SITES: BRIEF DESCRIPTION 
